\title{
A SURVEY \\ OF CANADIAN PLANTS IN \\ RELATION TO THEIR ENVIRONMENT
}

\author{
$\mathrm{BY}$ \\ JOHN ADAMS, M.A.
}

\section{DOMINION OF CANADA DEPARTMENT OF AGRICULTURE BULLETIN NO. 58-NEW SERIES}

630.4 C212

DIVISION OF BOTANY DOMINION EXPERIMENTAL FARMS

\section{B 58} new ser. 



\section{CONTENTS}

CHAPTER $\quad$ PAGE

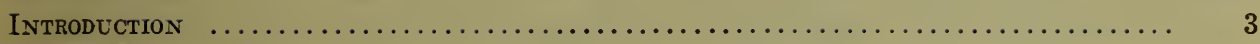

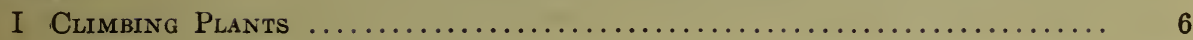

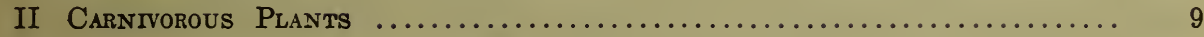

III Parasitic and Saprophytic Plants................................ 11

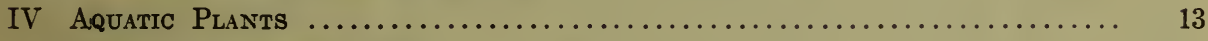

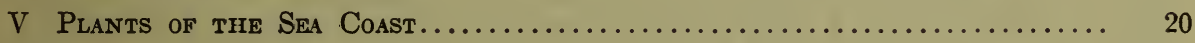

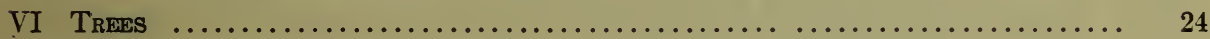

VII Plants with Protective Devices............................... 28

VIII Plants containing Resin, Volatile OIr, oR Minkx Juice............. 30

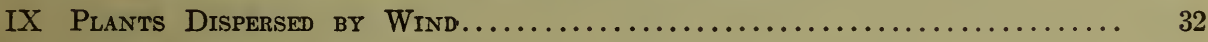

$\mathrm{X}$ Plants Dispersed bX Animals.................................. 33

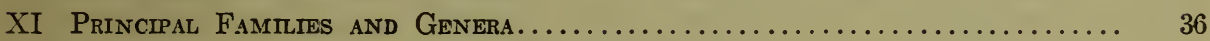

XiI Climate and Floral Regions of Canada........................... 38

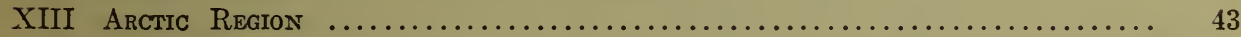

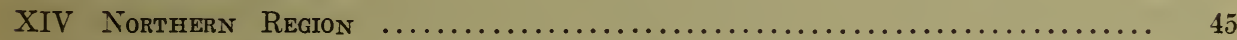

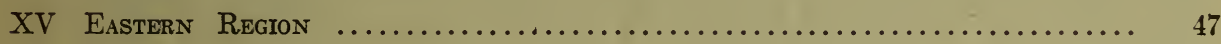

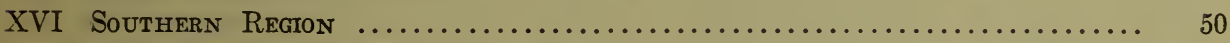

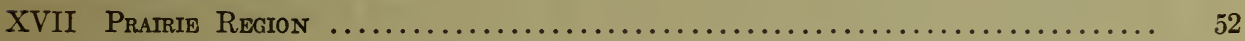

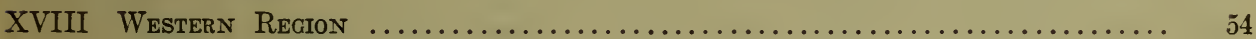

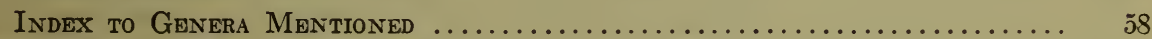





\section{A Survey of Canadian Plants in Relation to Their Environment}

\section{INTRODUCTION}

A considerable number of inquiries are received every year in reference to literature dealing with the wild plants of Canada. With the exception of the special bulletins dealing with Weeds, Medicinal Plants, and Poisonous Plantsall published under the direction of the Department of Agriculture-we have practically nothing to send out in response to this request. It is hoped, however, that the material contained in the present review of the Canadian Flora may serve in some measure to fill the gap.

It is quite unlikely that a work dealing in a systematic way with all the species of plants found in Canada will be published in the near future. In a country of such enormous dimensions with an extension of some 3,000 miles from the Atlantic to the Pacific, it is, moreover doubtful whether such a work is desirable. A less pretentious publication dealing with a more restricted area, such as Eastern Canadai or the Prairie Provinces, would probably be more useful to persons residing in those localities. But while a student should first make the acquaintance of the wild plants of his own township, or county, his knowledge should not end there. He should know something of the relation of plants to the various types of climate found in Canada and how this relation influences their geographical distribution; he should, moreover, be taught to "consider the Dominion as an entity, not as a nine-fold division." Had it not been for the foresight of Canada's pioneer botanist, Prof. John Macoun, in bringing botanical knowledge to 'bear on the relation of climate to plant-forms, how long might the development of our great Canadian Northwest have been postponed?

A work dealing with systematic botany is apt to prove somewhat dry reading. On the other hand, the consideration of plants viewed as living beings in reference to their various habitats, or the study of the various modifications by means of which plants adjust themselves to their environment is much more likely to arouse the interest of the average student. The identification of many plants may also be facilitated by the use of the "vegetation-group" arrangement. A person can see at a glance whether a plant is a climbing or aquatic plant or whether it is provided with spines or has milky juice. As all the Canadian Families or Genera belonging to each vegetation-group are enumerated in the various chapters it is comparatively easy by a process of exclusion to arrive at the name of the genus.

The present outline deals only with the higher, or seed-bearing plants. Out of a total of 680 genera of seed-plants occurring within the Dominion of Canada 487 are mentioned in the present work. The geographical distribution in Canada of most of these genera is indicated, while in the first ten chapters various physiological and morphological features are dealt with.

Technical terms have been used sparingly, but an acquaintance with some elementary work on the botany of the higher plants is presupposed. Each chapter is, for the most part, complete in itself.

No reference is made to plants which have been introduced into Canada from other countries. Only native or, more correctly speaking, aboriginal plants are dealt with; that is, plants which have not at any time been introduced directly or indirectly by human agency.

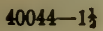


With reference to the Latin or scientific names employed, the International Rules in use for species, genus and family have been adopted throughout. Where there is any ambiguity an alternative name is given in brackets. For several reasons the author's name for the species has not been given. As a general rule the authority for the name of any species cannot be remembered for any length of time. Moreover, the bare mention of an author's name in many cases is not sufficient to distinguish the species without the full reference and date of the work in which the species was described, and this would obviously be out of place in a work of this kind.

With regard to the boundaries of a species, or a genus, or a family, there is a wide difference of opinion. Bearing this in mind, the number of species of any genus occurring in Canada must be taken only as an approximation. With regard to the limits of a genus, the idea followed has been mainly the conception of Bentham and Hooker's "Genera Plantarum", as this work represents a middle course between the views of various extremists.

As far as possible English names have been given for each species, in addition to the Latin name, the latter being placed in brackets immediately after the English name.

It may be useful to the student to mention a few of the more important books treating on the various topics dealt with in this work.

As general works of reference, mention may be made of Kerner's "Natural History of Plants", London, 1887-91; Schimper's "Plant Geography", Oxford, 1903; Warming's "Ecology of Plants", Oxford, 1909; Clements' "Plant Succession", Washington, 1916; Clements' "Plant Indicators", Washington, 1919; Livingston and Shreve's "Distribution of Vegetation in the United States as related to Climatic Conditions", Washington, 1921; and Willis's "Flowering Plants and Ferns", Cambridge, 1919.

Climbing Plants are dealt with in Darwin's "Movements and Habits of Climbing Plants", London, 1875; and Watson's "Climbing Plants", London, 1916.

Carnivorous Plants are described in Darwin's "Insectivorous Plants", London, 1875.

Information on Aquatic Plants will be found in Whipple and Ward's "Fresh Water Biology", New York, 1918, and Arber's "Water Plants", Cambridge, 1920.

Plants of the sea-shore are dealt with to some extent in Townsend's "Sand Dunes and Salt Marshes", Boston, 1913, and Carey and Oliver's "Tidal Lands; a Study of Shore Problems", London, 1918.

On the subject of trees, Sargent's "Manual of the Trees of North America", New York, 1906; Matthews' "Field Book of American Trees and Shrubs", New York, 1914; and Trelease's "Winter Botany", Urbana, 1918, will be found useful.

Poisonous plants' are dealt with in Thomson \& Sifton's "Poisonous Plants of Canada", Toronto, 1922.

For topographical distribution the most complete work is Macoun's "Catalogue of Canadian Plants", Montreal, 1883-1902. Eastern Plants are described in Gray's "New Manual of Botany", New York, 1908; in Britton and Brown's "Illustrated Flora", New York, 1913; and in Nichols' "Vegetation of Northern Cape Breton Island, Nova Scotia", 1918.

Prairie species are dealt with in Hales' "Selected Western Flora", Toronto, 1915, and in Rydberg's "Flora of the Rocky Mountains and Adjacent Plains", New York, 1917. Jackson, Higham, and Groh's "Check List of Manitoba Flora". 1922, has been issued by Manitoba Agricultural College, Winnipeg.

The plants of the Western Mountains are described in Brown and Schaffer's "Alpine Flora of the Canadian Rocky Mountains", New York, 1907; Henshaw's 
"Wild Flowers of the North American Mountains", New York, 1915; and Clements' "Rocky Mountain Flowers", New York, 1917.

The plants of the Dry Belt and Coast Region of British Columbia will be found included in Frye and Rigg's "Elementary Flora of the Northwest", New York, 1914; Henry's "Flora of Southern British Columbia and Vancouver Island", Toronto, 1915; and Piper and Beattie's "Flora of the Northwest Coast ", Pullman, 1915.

While the above titles refer to books, there are several minor publications of the nature of bulletins, etc., published by the Dominion Government. The Department of Mines has issued Dodge's "Flowering Plants and Ferns of Point Pelee, Ontario," Ottawa, 1914; Macoun and Malte's " Flora of Canada," Ottawa, 1917; Macoun and Holm's "Report of the Canadian Arctic Expedition 1913-18, Botany," Ottawa, 1921-22; and St. John's "Botanical Exploration of the North Shore of the Gulf of St. Lawrence," Ottawa, 1922.

The Department of the Interior has issued a very comprehensive Bulletin by Morton and Lewis on "Native Trees of Canada," Ottawa, 1917, while the Department of Agriculture has published Miss F. Fyles' "Principal Poisonous Plants of Canada, Ottawa, 1920.

Finally, the data referring to the climate of the country will be found in the "Monthly Record of Meteorological Observations," issued regularly by the Meteorological Service of Canada, Toronto.

It may be advisable to add here a few remarks on the method of finding the name of any of the plants mentioned. Supposing the plant in question to be the Yellow Waterlily we naturally turn to Chapter IV on Aquatic Plants. The first section of these is divided into two groups, namely $(a)$ plants without any distinction between stem and leaf, and $(b)$ plants with leaves. The Yellow Waterlily obviously belongs to the latter section in which the figure 3 at the right hand margin indicates that we are next to consult section 3. Passing on to section 3 we find that it is divided into four groups the second of which is "plants with some or all of the leaves floating on the surface." As this is the only group of the four into which the Yellow Waterlily will fit we pass on next to section 10. This section consists of three groups, depending on the shape of the leaves. As the leaves of the Yellow Waterlily are neither linear nor elliptical but come under the cordate or reniform group we pass on to section 13. Of the five plants included in this group only one has yellow flowers, namely, the Yellow Waterlily. 


\section{CHAPTER I}

\section{CLIMBING PLANTS}

In some plants the stem is too weak to enable the plant to stand erect but by developing a climbing habit and attaching themselves to other stronger plants this difficulty is largely surmounted. If no suitable support is within reach, the stem lies prostrate on the ground and continues its growth for a time until it can come across some suitable object to lay hold of. Climbing plants are characterized by comparatively long internodes, the possession of which enables them to reach the light sooner. In such long stems conducting tissue is specially well developed, while mechanical or supporting tissue is very poorly represented.

Among Canadian Monocotyledons there are only two genera which possess the climbing habit, namely Dioscorea and Smilax. In both of these, the leaves are net-veined like those of Dicotyledons. Among Dicotyledons the more important families in which climbers occur are Leguminosae, Convolvulaceae, and Cucurbitaceae, but various individual genera belonging to other families possess the climbing habit as well. Five methods of climbing are exhibited by Canadian species. These are described below:-

\section{Roots}

In this group roots develop along one side of the stem. They grow away from the light and become attached to the crevices in the bark of trees or other suitable objects. They also secrete an adhesive substance. This method occurs in a variety of Poison Ivy.

\section{Twining}

In this group the tip of the young stem revolves slowly in a circle as it grows and if it comes in contact with the stem of some other plant of suitable diameter it twines around it, forming a spiral. Only the uppermost two or three internodes have the power of movement or circumnutation and the time taken to complete one revolution varies in different species; in the Great Bindweed it is one hour and forty-three minutes. The particular direction which the stem takes in twining is inherent and is constant for each species. The commonest method is that which is opposite to the direction of movement in the hands of a watch. This means that if the tip of the twining stem be viewed from above the movement will be in the opposite direction to that of the hands of a watch, when lying flat with the face upwards. That the direction of twining is strongly inherent may be proved by gently twisting the growing tip of the stem two or three times round the support in the opposite direction to that in which it has been growing and tying it above and below with a soft string. It will be found that the part above the upper ligature reverts at once to the former method of twining.

The circumnutation of the growing tip in a gradually widening circle is a great aid in assisting the plant to find a suitable support; it also enables it on arrival at the summit of one stem to reach across and twine around another taller one. In the absence of some such support several stems frequently twine round each other. Besides undergoing circumnutation the stem undergoes twisting on its own axis. A firmer hold on the supporting stem around which it twines is afforded by the downwardly projecting hairs present on the young stems of many twiners such as the Ground Nut and Wild Peanut. 


\section{Leaf Stalks}

The stalk of the whole leaf or of some of its segments makes a complete turn around a small twig, or other suitable support and in this way the plant can readily ascend over shrubs or the lower branches of trees. The Virgin's Bower (Clematis) is an example.

\section{TENDRILS}

These are thread-like organs which are very sensitive to contact. In the Wild Balsam-apple and species of Wild Grape they are branched, while in Smilax they are unbranched. As regards their morphology, the group of tendrils in the Grape represents a modified branch and presumably the tendrils in the family Cucurbitacece are similar in nature; the tendrils of the Vetch correspond to leaflets while in Smilax they occupy the position of stipules, but are considered by some authorities as outgrowths of the petiole.

The tendril when young is nearly straight with a slight curvature at the tip. Like the stems of twiners, they circumnutate and thus increase the probability of finding a suitable support. The side of the tendril in contact with a support grows less rapidly than the free side, and the result is that the tip of the tendril soon makes several turns around the twig until all that part of the tendril beyond the point of first contact becomes wound up. The straight intervening part of the tendril in the case of Cucurbitaceo then becomes coiled into a spiral, but one-half of the spiral is coiled in one direction and the other half in the opposite direction. This reversal of the spiral is for mechanical reasons. If a stout wire which is attached at each end were twisted into a spiral the coil would tend to return to the original position when the twisting force is withdrawn. But, if the two halves are twisted in opposite directions, the tendency of one half to untwist balances that of the other and a state of equilibrium results. The spiral coiling of the tendril pulls the stem of the plant up nearer the support and at the same time protects it against the effects of violent gusts of wind. A sudden jerk merely loosens the coils of the spiral, whereas if the tendril remained straight it would be liable to snap across. In the outer cell wall of the tendrils of Cucurbitaceœ there are small pits filled with protoplasm which is continuous with the protoplasm of the cell. These are known as "contact papillæ" and are supposed to be specially adapted for the reception of stimuli.

In the Virginia Creeper the tendrils avoid the light and develop at their tips adhesive discs which secrete a sticky substance. They are thus enabled to climb up the steep faces of rocks.

\section{Hooks}

The hook-climbers or scramblers have recurved prickles on the stem which enable them to grow up through or scramble over the surface of other vegetation. This type occurs in Tear-thumb and Rose.

KEY TO CANADIAN SPECIES

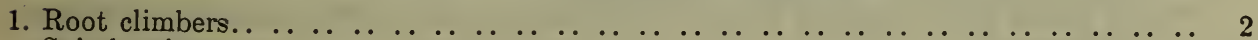

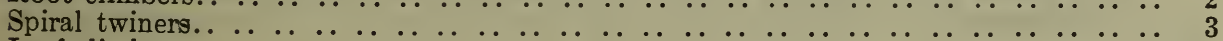

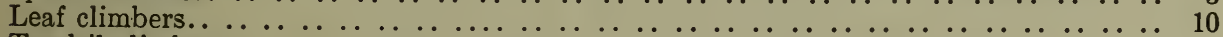

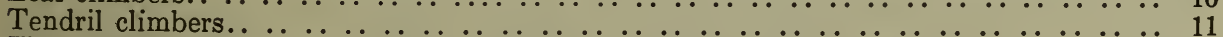

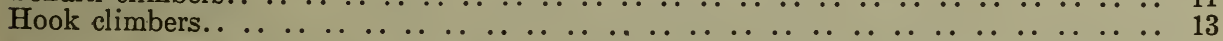

2. Leaves alternate, with three leaflets. Corolla green. Fruit a drupe. Widely distributed = Poison Ivy (Rhus Toxicodendron).

buted $=$ Poison Ivy (Rhus Toxicodendron).
Leaves opposite, pinnately compound. Corolla scarlet. Fruit a capsule. Occurring only on Pelee Island in Lake Erie = Trumpet Creeper (Tecoma radicans).

3. Woody twiners or lianes. . . . . . . . . . . . . . . . . . . . . . 4

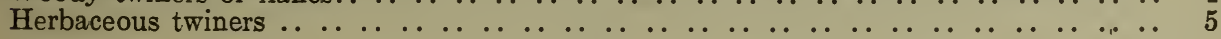


4. Leaves mostly broader than long and palmately veined. Stamens indefinite. Fruit a drupe with moon-shaped seeds. Eastern = Moonseed (Menispermum canadense).

Leaves twice as long as broad. Stamens five. Fruit a capsule. Seeds with a scarlet aril. Eastern $=$ Staff Tree (Celastrus' scandens).

Leaves opposite, the upper connate. Corolla sympetalous. Ovary inferior. Fruit a berry. Widely distributed = Honeysuckle (Lonicera $s p$.).

5. Parasitic plants with chlorophyll = Dodder (Cuscuta).

Green plants with simple leaves.. . . . . . . . . . . . . . . . . . . . . . . . . . . . . . . 6

Green plants with compound leaves and stipules. Fruit a legume.. $\ldots \ldots \ldots \ldots$. . . . . $\quad 99$

6. Leaves palmately veined, acuminate. Flowers unisexual. Fruit a capsule. Southern Ontario only $=$ Wild Yam-root (Dioscorea villosa).

Leaves opposite. Flowers in heads. Each head contains four flowers and has four bracts at the base. Southern Ontario only = Climbing Hemp-weed (Mikania scandens).

Stipules united to form a sheath. Perianth five-lobed. Fruit three-sided, one-

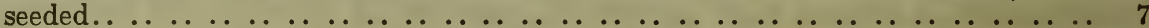

Plants with milky juice in the younger parts and with large funnel-shaped corolla. 8

7. Stipular sheath fringed. Eastern $=$ Fringed Black Bindweed (Polygonum cilinode).

Stipular sheath smooth. Widely distributed=Climbing False Buckwheat (Polygonum scandens').

8. Leaves triangular. Widely distributed = Great Bindweed (Calystegia sepium).

Root large and fleshy. Leaves cordate. Seeds hairy. Southern Ontario $=$ Wild Potato Vine (Ipomoea pandurata).

9. Underground tubers arranged like a necklace: Leaves pinnately compound. Eastern $=$ Groundnut (Glycine Apios).

Perennial plants with small underground tubers. Leaves with three leaflets. Flowers in racemes. Eastern $=$ Hog Peanut (Amphicarpaea comosa).

Annual plants. Leaves with three leaflets. Flowers in heads. Eastern $=$ Trailing Wild Bean (Strophostyles helvola).

10. Woody plants with opposite compound leaves. Fruits with persistent plumose style. Widely distributed = Virgin's Bower (Clematis $s p$.).

Biennial herbs with alternate leaves. The four petals are united together. Eastern = Climbing Fumitory (Adlumia fungosa).

11. The tendrils occupy the position of stipules, arise one at each side of the leaf-base and are unbranched. Leaves simple. Eastern $=$ Carrion Flower, and Greenbriers (Smilax sp.).

The tendrils represent modified leaflets. The leaves are pinnately compound. Widely distributed = Vetch (Vicia) and Vetchling (Lathyrus).

The tendrils are branched. Leaves palmately veined or palmately compound..... 12

12. Annual herbs. Fruit prickly, four-seeded. Eastern and Prairie $=$ Wild Balsam Apple (Echinocystis lobata).

Annual herbs. Fruit prickly, one-seeded. Eastern = One-seeded Bur-cucumber (Sicyos angulatus).

Woody plants. Leaves palmately lobed. Fruit a blue or blackish berry. Eastern and Prairie = Grape (Vitis $s p$.).

Woody plants. Leaves palmately compound. Fruit a bluish berry. Eastern and Prairie = Virginia Creeper (Parthenocissus quinquefolia).

13. Plants with arrow-shaped or halberd-shaped leaves. Stipules united to form a sheath around the stem. Eastern and Prairie = Tear-thumb (Polygonum sp.).

Leaves in apparent whorls, simple. Petals four in number, united. Ovary inferior. Widely distributed = Bedstraw (Galium sp.).

Woody plants with compound leaves. Petals five, separate $=$ Rose (Rosa) and Bramble (Rubus sp.). 


\section{CARNIVOROUS PLANTS}

While the great majority of plants obtain the nitrogen necessary for their growth and development from the nitrates present in the soil, there are a few which resemble animals in the fact that they utilize the bodies of small animals for this purpose. There are three families in the Canadian Flora which possess this property, namely, Sarraceniacen, Droseracece, and Lentibulariacece. The first contains one species, the Pitcher Plant or Side-saddle Flower (Sarracenia purpurea), to the second belong the Sundews (Drosera), while the third includes the Butterworts (Pinguicula) and Bladderworts (Utricularia). While these plants possess chlorophyll and can live for a time at least without organic food, it has been shown by experiment that some of them thrive better and increase more rapidly in weight when supplied with small pieces of animal flesh.

The leaves of the Sundew are covered with tentacles which secrete a sticky fluid in which insects are held firmly until they die. The tentacles also secrete an acid fluid containing an enzyme or ferment resembling pepsin, which digests the body of the insect, the digested products being gradually absorbed by the leaf. The process of digestion in the Butterworts is similar to that of the Sundews.

In the pitchers of Sarracenia and presumably also in the bladders of Utricularia no enzyme is secreted. Here bacterial decomposition of the body of the animal takes place and the soluble nitrogenous substances formed are probably absorbed.

The Pitcher Plant (Sarracenia purpurea) occurs in peat bogs. The leaves are arranged in the form of a rosette and are tubular. In addition to the tubular part the leaf has a flattened wing on the side nearest the centre of the plant and also a lid-like portion on the top. The concave surface of the lid is covered with downwardly projecting bristles, while the region inside the mouth of the tube is smooth and slippery. The Pitchers collect rain in which insects are eventually drowned, being prevented from crawling out by the smooth zone and the palisade of bristles.

The Sundews (Drosera) likewise occur in bogs and also have the leaves arranged in a rosette. The upper side of the leaves is covered with the glandular tentacles which secrete a sticky fluid. The tentacle is shaped like a small pin and contains a small vascular bundle, the secretion being formed by the headlike part. Small insects alighting on the leaf are held fast and the stimulus is conveyed from the tentacle which has been touched to all the others on the leaf, which thereupon begin to bend over until eventually they touch the animal's body. After a time the insect is suffocated by the sticky fluid and after its body has been digested and the soluble parts absorbed the tentacles again bend outwards and resume their former position. The name Sundew refers to the sticky secretion which glistens in the sun like dew.

The Butterworts (Pinguicula) are also rosette plants. The leaves are flat but have the edges rolled slightly inwards and the upper surface is covered with glands which secrete a sticky mucilage. Small animals alighting on the leaf are held fast, the edges of the leaf curving still further towards the median line so as to prevent escape. Secretion of acid and ferment and absorption of the digested products occur similar to that which happens in the Sundews. Then the edges of the leaf gradually roll back to their normal position. The name is derived from the Latin pinguis fat, as the leaves have a greasy appearance. 
The Bladderworts (Utricularia) are mostly water plants, destitute of roots, with horizontal elongated stems and leaves divided into filiform segments. Towards the approach of winter the last-formed internodes are very short and each successive leaf is closely wrapped round those internal to it, the final result being a small globular structure resembling a green pea. These "winter buds" rest on the bottom until spring, when they resume their growth and gradually rise to the surface again. The bladders occur on the leaves and are provided with a valve opening inwards and forming a sort of trap-door. The mouth of the bladder is generally fringed with bristles. The sides of the bladders are drawn in when empty and a sudden touch on the sensitive bristles causes the bladder to expand violently, thereby sucking in small aquatic animals such as Crustaceans, which are unable to escape and eventually die. Glandular hairs occur on the inside of the bladder and it is very probable that the products of decomposition of the animal's body are absorbed by these hairs. The name is derived from the Latin utriculus, a little bag.

The Canadian species of carnivorous plants may be grouped as follows:-

1. Rootless water plants with divided leaves bearing small bladders. Flowers mostly in racemes rising above the surface of the water. The corolla is twolipped and spurred: only two stamens are present. This group includes the Bladderworts (Utricularia), of which there are ten species.

The Great Bladderwort (Utricularia vulgaris) is the largest and has the bladders uniformly distributed on the leaves. It occurs across Canada.

The Flat-leaved Bladderwort (U. intermedia) has the bladders confined to special branches while other branches have flat green leaves without bladders. Like the previous species, it is widely distributed.

In the One-flowered Bladderwort (U. resupinata) the flowers are solitary, purple in colour, and the bladders are without bristles. It is an eastern species.

The Horned Bladderwort (U. cornuta) has linear, erect, grass-like leaves and also colourless leaves which bear bladders. The bladders have no bristles. Eastern.

2. Land plants, with the leaves in a rosette.

(a) Pitcher Plant or Side-saddle Flower (Sarracenia purpurea). The leaves are tubular with a lid-like portion at the free end. The flowers are large and solitary and the style is expanded at the top like an umbrella. The range is eastern and northern.

(b) Butterwort (Pinguicula). The leaves have the edges inrolled and the upper surface is covered with glands. Flowers solitary. Corolla two-lipped and spurred. There are two stamens.

There are three Canadian species, one of which, the Common Butterwort (Pinguicula vulgaris) with violet flowers, is widely distributed.

(c) Sundew (Drosera). Leaves flat, covered with adhesive tentacles, circinate when young. Flowers small, in a raceme. There are four Canadian species, the commonest of which is the Round-leaved Sundew (Drosera rotundifolia). It is widely distributed. 


\section{PARASITIC AND SAPROPHYTIC PLANTS}

Among the higher plants there are a few families that have no chlorophyll and are therefore unable to manufacture organic substances out of simple inorganic materials. In this respect they resemble the larger Fungi and, like them, may be divided into two biologic groups, namely Saprophytes and Parasites. Saprophytes live on decaying substances such as the leaves on the floor of a forest while Parasites obtain their nourishment from other living plants to which they are attached by special organs. The Family Monotropaceœ is saprophytic while Orobanchacee is parasitic. The genus Arceuthobium possesses chlorophyll and is therefore semi-parasitic. This method of life is found in some other genera such as Comandra, Pedicularis and its allies, but as they are attached to the roots of other plants the semi-parasitic habit is not at all obvious without careful examination.

In those species in which chlorophyll is absent, or nearly so, the leaves, not being functional, are reduced to scales, and the only conspicuous part of the plant is the inflorescence. The root system is very much reduced or may be entirely absent. The roots of saprophytes are covered with a mantle of fungusfilaments known as a mycorhiza which serves to break up the organic substances present in the soil and also absorbs water for the plant in the same way as root-hairs. As Corallorhiza has no roots, the mycorhiza covers the muchbranched rhizome.

Parasitic plants are attached to their hosts by special organs known as suckers or "haustoria." The members of the family Orol)anchacece are rootparasites, while Cuscuta is a twining stem-parasite.

When the seed of Cuscuta germinates it produces a short root which has only feeble penetrating power and does not branch in the soil, and a yellowish thread-like stem without any indication of cotyledons. The stem moves around slowly in a circle as it grows forward and if it comes in contact with a suitable plant it twines around it and develops haustoria at various points, after which the root dies and the parasite loses all connection with the ground. If it does not find a suitable plant to lay hold of, the seedling perishes. The penetration of the haustorium into the tissues of the host plant appears to be aided by ferments which act on and dissolve the cellulose wall of the cells. The vascular tissues of the host and parasite enter into intimate relation resembling that of a scion when grafted on to the stock of another plant.

In Orobanchacece the seed on germination produces a root of the usual type which ramifies in the ground. One of the roots develops a haustorium where it comes in contact with a suitable plant. With the exception of the inflorescence the plant lives entirely under ground and stores up reserve material in its tissues. After a longer or shorter interval the flowering shoot comes above the ground and ripens and scatters its seeds in the usual manner.

Green semi-parasites appear to absorb only water and inorganic substances in solution from the plants to which they are attached. The seeds of both saprophytes and parasites are very small and numerous. 


\section{KEY TO CANADIAN SPECIES}

1. Twining plants, without chlorophyll, with flowers in clusters. Fruit a capsule containing one to four seeds. Widely distributed = Dodder (Cuscuta).

Green parasites, attached to the bark of coniferous trees. Leaves opposite, connate and reduced to scales. Fruit a one-seeded berry. Widely distributed $=$ Dwarf Mistletoe (Arceuthobium).

Plants with little or no chlorophyll, growing on decaying vegetation or the roots of other plants. . . . . . . . . . . . . . . . . . . . . . . . . .

2. Plant waxy white with creeping rhizome. Flowers zygomorphic with 3 sepals and 3 petals but there is no spur. Ovary inferior. Western= Phantom Orchid (Cephalantherc Austinae).

Rhizome with numerous short coralloid branches. Flower zygomorphic, with three sepals and three petals, and a short spur. Ovary inferior. Widely distributed = Coral-root (Corallorhiza).

Plants with some chlorophyll and opposite scaly leaves. Sepals and petals four. Ovary superior. Eastern = Bartonia (Bartonia).

Flowers actinomorphic. Stamens usually ten. Carpels four to five. (Fam. Mono-

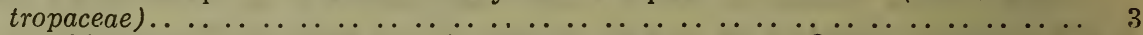

Corolla bilabiate. Stamens four. Ovary one-celled. (Fam. Orubanchaceae)..... 4

3. Flowers in a dense spike. There is no corolla. Western = Spike-flowered Allotropa (Allotropa virgata).

Base of stem enlarged and bulb-like. Flowers in racemes, drooping. Petals united. Widely distributed $=$ Pine Drops (Pterospora andromedea).

Plants with white stems and white solitary nodding flowers which turn black on drying. Petals free. Widely distributed = Indian Pipe (Monotropa uniflora).

Flowers in a nodding raceme. Petals free. Widely distributed=Pine-sap (Hypopitys $s p$.).

Flowers in a dense spike. Ovary one-celled. Western $=$ Cone Plant (Hemitomes congestum).

4. Inflorescense branched. The lower flowers do not open but set seed while the upper flowers open but set no seed. Eastern, occurring on the roots of Beech $=$ Beechdrops (Epiphegus virginiana).

There are but two bracteoles under the calyx which is slit down one side. Stamens exserted, with bristly anthers. Capsule two-valved. Occurs in Southern Ontario = Squaw Root (Conopholis americana).

There are one to two bracteoles under each of the usually sessile flowers. Western = Broomrape (Orobanche sp.).

Flowers stalked, without bracteoles. Widely distributed $=$ Ghost Pipes: Cancer Root (Thalesia sp.).

There is a globose, tuberous, underground stem with densely imbricated scaly leaves. Capsule four-valved. Western = Poque (Boschniakia Hookeri). 


\section{CHAPTER IV}

\section{AQUATIC PLANTS}

Aquatic plants or hydrophytes normally grow with their stem and most of the leaves immersed in the water or floating on its surface. Where a.erial leaves occur they are mostly found only in connection with the flowering shoots. Between aquatic plants on the one hand and land plants on the other various transitional forms occur in swamps and marshes; indeed among the true aquatics there are some such as Shore-weed (Littorella uniflora) which are able to live for a time on land.

While a rigid definition of what constitutes a swamp or a marsh is somewhat difficult, nevertheless some definition of the terms must be attempted and, even if artificial, it should be such as can easily be recognized in field practice.

A swamp is taken to mean a place that does not dry up in summer, and on which the vegetation covering it is not sufficiently firm to bear the weight of an average person.

A marsh, while permanently wet, may, however, be trodden on by human beings without sinking into it.

In both swamp and marsh plants the leaves are fully exposed to the air just as they are in ordinary land vegetation.

Some of the more important adaptations shown by aquatic plants to their surroundings are set forth below. All the examples quoted are Canadian species. To avoid repetition the English names are given at the end of the chapter only.

1. As water plants are less subject to climatic influences than land plants and derive their nourishment mainly from the surrounding medium they exhibit in a special degree marked vegetative growth. In Elodea canadensis and Potamogeton Robbinsii fruits are seldom found.

Most water plants are perennial herbs; the annual type is rare, but is exemplified by Najas flexilis and Subularia aquatica.

In temperate climates hibernation takes place in various ways during the winter months. Those species which creep in the mud at the bottom have branching rhizomes or long runners and are social in habit and are already sufficiently protected in winter as water seldom freezes to the depth at which they occur. In the autumn the intercellular spaces present in Lemna minor become filled with water and the plant sinks. In some species the end of the shoot swells and is closely enveloped by the young leaves forming a small globular "winter bud" which falls to the bottom and resumes growth in the following spring. These winter buds are exemplified by Utricularia and Ceratophyllum. Special short winter shoots or "hibernacula" occur in some species of Potamogeton such as $P$. Friesii, P. pusillus, and $P$. zosterœfolius.

2. There are three principal types of assimilatory shoot:-

(a) The rosette type found in Lobelia Dortmanna, Subularia aquatica, etc. The stem is short, vertical, and unbranched, with very short internodes.

(b) The horizontal type is found in the Family Nymphaeaceae. The stem creeps in the mud and bears long-stalked floating leaves.

(c) The long-stemmed type occurs in Myriophyllum, Potamogeton, etc. From the creeping rhizome erect green stems arise which branch freely and bear numerous leaves. In Elodea canadensis all the leaves are submerged but in some species of Potamogeton and Callitriche both floating and submerged leaves may occur. The stems are long and flexible and show no increase in thickness. 
3. The roots of plants serve mainly a twofold function. One is to anchor the plant in the soil, while the other is to absorb water and mineral substances, the latter function in land-plants being restricted for the most part to that region of the root which is clothed with root-hairs. Plants which grow in still water may be devoid of roots. This condition is found in Wolffia, Ceratophyllum, and Utricularia. The roots of Lemna do not branch, soon cease to grow and merely hang down into the water. In most aquatic plants the roots ramify through the mud. The roots of Myriophyllum and Hippuris are said to be devoid of root-hairs. In most other aquatic plants, however, careful investigation has shown that root-hairs are present and that they absorb mineral matter from the substratum.

4. Air-spaces are abundant in the stems and leaves of water plants. They serve to give buoyancy to the plant and also for the passage of gases throughout the tissue.

5. As water cuts off a considerable amount of light it follows that plants growing in this medium are on the same footing as shade-plants and hence the internodes are more elongated than in the case of plants fully exposed to the sun.

6. The cuticle or corky layer of the external cell wall of the epidermis is very thin or absent in the submerged parts of water-plants. In consequence of this arrangement the absorption of water and substances in solution becomes possible over the entire surface of the plant. Chlorophyll is present in the external layer of cells and hairs are, as a rule, absent.

In plants with floating leaves there are various devices to prevent the upper surface from being wetted. In some species of Potamogeton there is a thin coating of wax while in Nelumbo lutea there is a fine covering of hairs. An incrustation of calcium carbonate occurs on the surface of most species of Potamogeton but is not found in Vallisneria even when growing in the same water as the former genus.

7. The vascular bundle system is feebly developed and is mostly central in position. As one important function of the vessels of the xylem is to convey water throughout the plant and as there is no necessity for such organs in a plant surrounded by water the reason for such reduction of the vessels becomes obvious. Pond states that "in Ceratophyllum the vascular system has become so simplified that its dicotyledonous relationship cannot be established by the stem structure."

The fact that the more rigid tissues of the plant are placed in the centre and the softer tissues outside, somewhat in the position of the backbone of a fish, makes bending much more easy of accomplishment as the result of currents or eddies in the surrounding medium.

8. Mechanical or supporting tissue, distinct from that found in the centrally placed vascular system, does not occur. The water tends to support the plant, being aided very materially by the air-spaces mentioned above. As waterplants are not subject to wind pressure the necessity for mechanical tissue does not arise.

9. The leaves of aquatic plants may be grouped under five main types:-

(a) The ribbon type occurs in Vallisneria and Zostera. This form is adapted to deep or running water.

(b) The oblong type occurs in Elodea, Hippuris, and various others.

(c) The awl-shaped type is found in Subularia and Littorella. Some members of this group can live for a time on land if the level of the water sinks.

(d) The thread-like or divided type occurs in Potamogeton pectinatus and Myriophyllam and others. This type allows currents of water to pass without any danger of tearing the leaf. It also exposes a greater surface to the water and thereby acquires more of the dissolved gases, thus furthering photosynthesis. 
(ie) The floating type found in Nymphaeaceae. The leaves of this group are usually entire and as they present a broad surface they are not easily submerged. In case the level of the water rises the petiole has the power of resuming growth so as to bring the blade again to the surface. In this group stomata occur on the upper surface of the leaf, the upper epidermis has no chlorophyll and there is frequently some arrangement to prevent the upper surface of the leaf from being wetted. Internally palisade tissue occurs towards the upper side and spongy tissue towards the lower.

In a number of species of Potamogeton, such as $P$. natans, both narrow submerged leaves and broad floating leaves occur on the same plant.

In Dicotyledons the submerged leaves are usually divided and the floating ones simple when both occur on the same plant.

As chlorophyll occurs in the epidermis of submerged leaves and as stomata are absent the submerged leaf is isobilateral in structure.

10. Mucilage is secreted by glands on the surface of some water-plants such as Brasenia Schreberi. Whether it serves to prevent too rapid diffusion of cell-sap from the interior of the plant or has some other function is not clear. In some cases it may be a protection against animals which feed on aquatic plants.

11. While the pollination of water-plants is in many cases accomplished by the same methods as that of land-plants, that is, by the agency of wind or insects, certain aquatic species have special methods peculiar to the group to which they belong. In Vallisneria the staminate flowers break off and float on the surface of the water, where some of them eventually come in contact with the stigma. In Ruppia the pollen grains float on the surface of the water, while in Najas, Zostera, Zannichellia, and Ceratophyllum the pollen grains, having the same specific gravity as the surrounding medium, float at any depth and are conveyed by the water. The pollen grains of such species have only a single coat.

Subularia aquatica is semi-cleistogamous. Vegetative reproduction is very marked among aquatic plants and in some species such as Lemna flowers are of rare occurrence. Many species ripen their fruits under water.

\section{KEY TO CANADIAN SPECIES}

1. Plants without any distinction between stem and leaf............... 2

Plants with leaves. $\ldots \ldots \ldots \ldots \ldots \ldots \ldots$

2. Plants mostly floating on the surface with unbranched roots which hang down into the water. Widely distributed = Duckweed (Lemna sp.).

Rootless plants, less than 1/18 of an inch in length, floating at or near the surface. Southern Ontario $=$ Rootless Duckweed (Wolffia).

3. Plants with all the leaves submerged. . . . . . . . . . . . . . . . . . . . . . 4

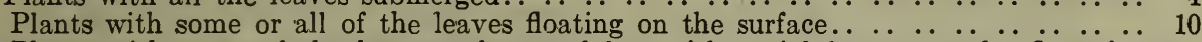

Plants with most of the leaves submerged but with aerial leaves on the flowering

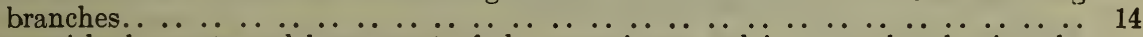

Plants with the roots and lower part of the stem immersed in water but having the

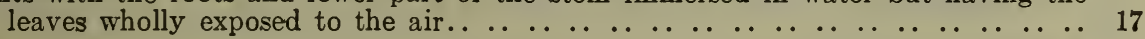

4. Plants living in the sea or in brackish water. . . . . . . . . . . . . . . 5

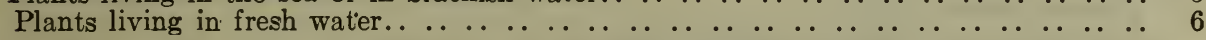

5. Annual plants with the flowers in a naked spike. Flowers monoecious, the staminate flower consisting of a single stamen and the pistillate of a single carpel. Vancouver Island = Flowering Quillwort (Lilaea subulata).

Perennial plants with a thick rhizome and grass-like leaves. Flowers dioecious, in two rows on a flat spadix. Pollen grains filamentous. On rocks between tidemarks on Vancouver Island = Sea Basket-grass (Phyllospadix). 
Rhizome slender, creeping. Leaves with three or more nerves. Flowers monoecious, borne on a spadix. Pollen grains filamentous. It occurs at low water mark on both the East and West coasts = Sea Eel-grass or Grass Wrack (Zostera marina).

Leaves threadlike, with sheathing base in which the two-flowered spadix arises. The flower has two stamens and four carpels. Pollen grains filamentous. The fruits have long stalks. Found in brackish water. Widely distributed $=$ Tassel Pondweed (Ruppia).

6. Leaves awl-shaped, in a rosette.. $\ldots \ldots \ldots \ldots \ldots \ldots \ldots \ldots \ldots \ldots \ldots \ldots$

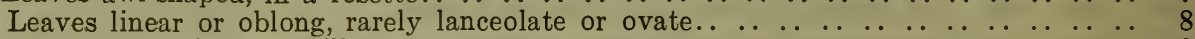

Leaves divided into capillary segments. $\ldots \ldots \ldots \ldots$

7. Roots fibrous and marked externally by transverse bands. Flowers monoecious, borne in a dense head on a naked peduncle. Eastern = Seven-angled Pipewort (Eriocaulon septangulare).

Annual plants with the flowers in a raceme. There are four white petals and six stamens. The pod dehisces by two valves when ripe. Widely distributed = Water Awlwort (Subularia aquatica).

Flowers monoecious, mostly solitary, wind-pollinated. Petals four, united. Stamens four. Fruit one-seeded and indehiscent. Eastern = Shore-weed (Littorella uniflora).

Leaves hollow, divided by a longitudinal partition. Flowers in a raceme. Corolla sympetalous, two-lipped, blue in colour. Widely distributed $=$ Water Lobelia (Lobelia Dortmanna).

8. Stoloniferous plants with ribbon-shaped leaves. The leaves have three or more principal veins. The stalk of the pistillate flower contracts into a spiral after fertilization and the many-seeded fruit ripens under water. Eastern=Eel-grass or Wild Celery (Vallisneria spiralis).

Annual plants with opposite, linear, finely toothed leaves. Flowers solitary in the axils of the leaves, the staminate consisting of a single stamen and the pistillate of two united carpels. Fruit one-seeded. Widely distributed = Water Nymph (Najas flexilis).

Leaves oblong, one-veined, usually in whorls of three or the lower opposite. Eastern and Prairie = Water-weed (Elodea).

Leaves opposite, narrow, one-veined. Flowers monoecious, in axillary clusters composed of one staminate and usually four pistillate flowers. Each flower consists of one stamen or one carpel. Fruit beaked. Widely distributed $=$ Horned Pondweed (Zannichellia palustris).

Flowers in a spike which projects above the water. The flower consists of four stamens and four separate carpels. From each of the sessile stamens a concave expansion grows out and in consequence the flower looks as if a perianth was present. Widely distributed $=$ Pondweed (Potomogeton sp.).

Leaves opposite, oblong, one-veined. Flowers monoecious, solitary in the axils of the leaves. The staminate flower consists of one stamen and the pistillate of two united carpels. Eastern $=$ Northern Water-starwort (Callitriche autumnalis).

9. Flowers solitary. Petals five, white. Stamens and carpels numerous. Widely distributed = Water Crowfoot (Ranunculus $s p$.).

Mostly annual plants, attached to stones in streams. The leaves are not very clearly marked off from the stem. Flowers solitary in the axils of the leaves, each enclosed in a spathe. Fruit a many seeded capsule. Eastern = Riverweed (Podostemum ceratophyllum).

Rootless plants with whorled leaves. Flowers unisexual, occurring singly in the axils of the leaves. Fruit beaked, one-seeded, and indehiscent. Widely distributed = Hornwort (Ceratophyllum demersum).

Rootless plants with small bladders on the leaves=Bladderwort (Utricularia). (See Chapter II).

10. Floating leaves linear.. . . . . . . . . . . . . . . . . . . . . . . . . . 11

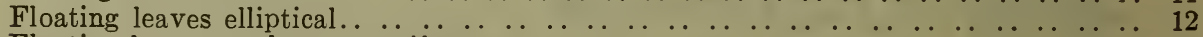

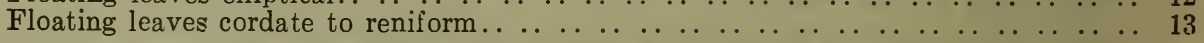

11. Flowers monoecious, in dense heads, the staminate occurring above the pistillate heads. Fruit one-seeded and indehiscent: Widely distributed=Bur-reed (Sparganium sp.).

Flowers solitary or two together, yellow. There is a perianth of six segments. Stamens three. Fruit a one-celled, many-seeded capsule. Eastern $=$ Water Stargrass (Heteranthera dubia). 
12. Stipular scales not enclosing the stem. Stamens four, each with a concave out-growth at the back. Widely distributed = Pondweed (Potamogeton sp.)

Stipules united to form a sheath around the stem. Perianth rose-coloured, composed of five segments. Stamens five. Widely distributed =Willow-weed (Polygomum amphibium).

Plants covered with a mucilaginous secretion. Leaves peltate. Flowers purple, with three sepals and three petals. Carpels separate. Eastern and Western $=$ Watershield

(Brasenia Schreberi).

13. Stoloniferous plants with monoecious white flowers. Perianth composed of six segments. Stamens united into a column. Fruit a berry. It occurs in Lake Ontario= Frog's Bit (Limnobium Spongia).

Sepals five or more, white or pink. Petais absent. Stamens numerous. Carpels separate, each forming a follicle when ripe. Widely distributed = Floating Marsh Marigold (Caltha natans).

Flowers yellow. Sepals five or more. Petals small, numerous, resembling stamens, inserted below the ovary. Carpels numerous, united. Widely distributed = Yellow Waterlily (Nymphozanthus).

Flowers white. Sepals four. Petals large, numerous. Stamens inserted on the ovary. Carpels numerous, united. Fruit ripening under water. Eastern and Prairie = White Waterlily (Nymphaea).

Plants with long slender stolons each of which bears a floating leaf and a cluster of flowers and tubers at the base of the leaf. Petals white, five in number, united. Stamens five. Carpels two, united. Eastern=Floating Heart (Nymphoides lacunosum).

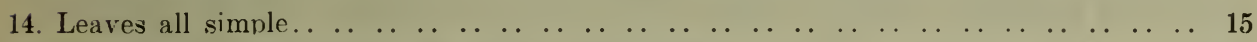

Submerged leaves divided into narrow segments. . . . . . . . . . . . . . 16

15. Leaves opposite, three-nerved. Flowers axillary and usually monoecious. Fruit fourseeded. Widely distributed = Water Starwort (Callitriche $s p$.).

There is one green aerial leaf and a tuft of capillary submerged leaves on the rhizome. Flowers hermaphrodite. Fruit a capsule with numerous seeds. Eastern $=$ Bayonet Rush (Juncus militaris).

Leaves whorled. Flowers axillary and usually hermaphrodite. Fruit one-seeded. Widely distributed $=$ Mare's Tail (Hippuris).

Leaves whorled. Flowers monoecious. The parts of the flower are in fours. Eastern $=$ Slender Water-milfoil (Myriophyllum tenellum).

16. Aerial leaves alternate, palmately divided. Petals five or more, yellow. Stamens and carpels numerous. The fruit consists of achenes. Widely distributed = Yellow Water-crowfoot (Ranunculus delphinifolivis).

Leaves alternate, the aerial ones lanceolate and serrate. Flowers in a raceme. Petals four, white. Stamens six. Pods opening by two valves. Eastern = Lake Watercress (Nasturtium aquaticum).

Leaves whorled. Flowers axillary. Parts of the flowers in fours. Widely distributed = Water Milfoil (Myriophyllum).

Leaves alternate, the submerged ones pectinate, the aerial either lanceolate or pectinate. Petals absent. Eastern = Mermaid-weed (Proserpinaca).

Leaves opposite, the aerial ones lanceolate and serrate. Flowers yellow, in heads, with both disc and ray flowers. The fruit is barbed. Eastern $=$ Water Marigold (Megalodonta Beckii).

17. Leaves reduced to scales, stem terete. . . . . . . . . . . . . . . . . . . . . . . 18

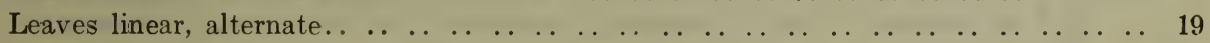

Leaves lanceolate, cordate, sagittate or orbicular in shape, alternate in position.. . 23

Leaves opposite or whorled, simple. . . . . . . . . . . . . . . . . . . . . 27

Leaves divided or compound, alternate. . . . . . . . . . . . . . . . . . . . . . . . . 28

18. Flowers in spikes which are grouped in an umbellate manner. Each flower occurs in the axil of a bract and has a perianth of bristles, three stamens, and two united carpels. Fruit one-seeded and indehiscent. Widely distributed=Great Bulrush (Scirpus validus) and Tule (Scirpus occidentalis).

Flowers with a perianth of six flat segments, three stamens and three united carpels Fruit a capsule with numerous seeds. Widely distributed=Soft Rush (Juncus effusus). 
19. Flowers grouped in a dense cylindrical inflorescence or in heads. . . . . . . . . .

Flowers in spikelets, the spikelets either solitary or more or less umbellately arranged. Flowers hermaphrodite, with a perianth of bristles or hairs......

Flowers monoecious, in spikes or in a branching panicle.. . . . . . . . . . .

20. Flowers in a dense terminal cylinder, monoecious, the staminate higher up and the pistillate lower on the stem. The pedicel of each flower bears a tuft of hairs. Widely distributed $=$ Cat-tail $($ Typha).

Flowers in globose heads, monoecious, the staminate heads occurring higher up on the stem than the pistillate. Fruit indehiscent, mostly one-seeded, with a pointed beak. Widely distributed = Bur-reed (Sparganium sp.).

The inflorescence is cylindrical and appears to be borne laterally on the angular scape but the upper part of the apparent scape is really a spathe. Perianth composed of six segments, Stamens six. Carpels two or three. Aromatic, eastern plants= Sweet Flag (Acorus Calamus).

Flowers in a terminal head. There are three sepals, three yellow petals, three stamens, and three carpels. Fruit a capsule. Eastern $=$ Northern Yellow-eyed Grass (X yris montana).

21. Spikelets solitary, terminal, not much thicker than the stem. Flowers hermaphrodite. The perianth consists of barbed bristles. Eastern=Spike-rush (Eleocharis sp.).

Spikelets solitary, or several together. Perianth hairs silky, much longer than the bracts. Widely distributed $=$ Cotton Grass (Eriophorum).

Stem triangular. The inflorescence consists of several spikelets with one or more leaflike bracts at the base. Widely distributed = Bulrush and Sword-grass (Scirpus sp.).

The lower scales of the spikelet have no flowers in their axils. The fruit is crowned by the persistent base of the style. Widely distributed = Beak-rush (Rhynchospora).

22. Stem mostly triangular. Flowers monoecious, both kinds occurring in the same spikelet or in separate spikelets. Stamens three. Fruit enclosed by a special bract (perigynium). Widely distributed $=$ Bottle Sedge (Carex $s p$.).

Stem rounded. Flowers monoecious, the pistillate above, the staminate forming. the lower part of the panicle. Stamens six. The pistillate flowers are long-awned. Eastern $=$ Wild Rice (Zizaria aquatica).

23. Leaves orbicular, peltate. Petals numerous, pale yellow. Stamens numerous, attached at the base of the ovary. Carpels numerous, separate, sunk in pits on the topshaped receptacle. Occurs in Lake Ontario = American Lotus (Nelumbo lutea).

Leaves lanceolate. . . . . . . . . . . . . . . . . . . . . . . . . . . . . . 24

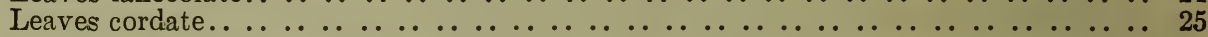

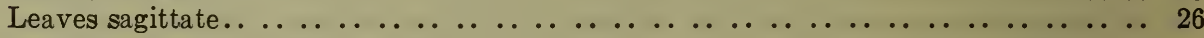

24. Sepals three. Petals three. Stamens six to nine. Carpels in one whorl. Widely distributed $=$ Water Plantain (Alisma Plantago-aquatica).

Sepals three. Petals three. Stamens six to nine. Carpels borne in several series on the receptacle. Occurs in Southern Ontario $=$ Dwarf Water Plantain (Echinodorus parvulus).

Flowers unisexual, in groups of three. The staminate flowers are uppermost on the stem. Stamens numerous. The fruit consists of numerous achenes grouped in a head. Eastern = Arrow-head (Sagittaria sp.).

Flowers in the axils of the leaves. The parts of the flower are in fours. Ovary inferior. Eastern = Seed-box, and Ludwigia (Ludwigia sp.).

Annual plants with runners, rooting at the nodes. The flowers occur singly and have five united petals and four stamens. Fruit a capsule which becomes one-celled when ripe. Widely distributed $=$ Mudwort (Limosella aquatica).

Stipules forming a sheath around the stem. Flowers in whorls with six perianth segments and six stamens. Fruit three-sided, one-seeded, and indehiscent. Eastern = Dock (Rumex sp.).

25. Flowers in a spadix with a white spathe. There is no perianth. Berries separate, red. Eastern = Water Arum (Calla palustris).

Flowers in a spadix with a purplish to greenish-yellow spathe. There is a perianth of four segments. The berries are immersed in the spongy axis of the spadix and are coherent with the perianth. Eastern = Skunk Cabbage (Symplocarpus foetidus).

Flowers in a long spike. There is no perianth. Stamens six to eight. Fruit separating when ripe into three or four one-seeded segments. Occurs in Southern Ontario= Lizard's Tail (Saumurus cernuus).

There are five or more brightly coloured sepals, no petals, and numerous stamens. The fruit is a group of follicles. Widely distributed = Marsh Marigold (Caltha sp.). 
26. The stem bears a single green leaf. Flowers in a spike, blue in colour. Perianth twolipped. Stamens six. Fruit one-seeded, indehiscent, enclosed in the persistent base of the perianth. Eastern = Pickerel Weed (Pontederia cordata).

Flowers unisexual, in groups of three. The staminate flowers are uppermost on the stem. Sepals three, green. Petals three, white. Stamens numerous. The fruit consists of numerous achenes in a head. Widely distributed=Arrow-head (Sagittaria sp.).

The flowers resemble those of Arrow-head in arrangement and structure except that the lower flowers are hermaphrodite while the upper are staminate. Eastern, occurring in brackish water = Sea-Arrow-head (Lophotocarpus spongiosus).

Flowers unisexual, in a spadix with a green spathe. The staminate flowers occur higher up on the spadix. There is no perianth. The fruit is a green berry. Eastern= Arrow Arum (Peltandra virginica).

27. Flowers solitary and axillary. The parts of the flower are in twos. Seeds with reticulate markings. Widely distributed = Water-wort (Elatine).

Stem creeping. Flowers axillary, sessile. The parts of the flower are in fours. Ovary inferior. Widely distributed=Marsh Purslane (Ludwigia palustris).

Flowers grouped in a nearly globular cluster. Petals five, united, yellow with black spots. Stamens five, in front of the petals. Ovary one-celled. Widely distributed =Tufted Loosestrife (Lysimachia thyrsiflora).

Plants with milky juice. Flowers umbellately arranged. Petals rose-coloured. Pollen grains grouped together to form pollinia. Fruit composed of two follicles. Seeds with a tuft of hairs. Eastern and Prairie = Swamp Milkweed (Asclepias incarnata).

Glabrous plants with flowers in axillary racemes. Sepals four. Petals four, unequal in size, united. Stamens two. Ovary two-celled. Widely distributed = Speedwell (Veronica sp.).

Flowers in small heads at the end of axillary peduncles. Corolla bilabiate. violet in colour. Stamens two. Eastern =Dense-flowered Water-willow (Dianthera americana).

28. Leaves pinnately compound, stipulate. Corolla purple. Stamens and carpels numerous. Widely distributed $=$ Marsh Cinquefoil (Potientilla palustris).

Stem hollow. Leaves mostly pinnately divided. Flowers in a compound umbel with bracts at the base. Each half of the fruit has eight or more oil-canals. Widely distributed = Water-parsnip (Sium).

Roots thick and fleshy. Stem hollow. Leaves bipinnately divided. Flowers in a compound umbel without bracts at the base. Each half of the fruit has six oilcanals. Widely distributed = Water Hemlock (Cicuta).

Stem creeping. Leaves ternately divided. Flowers in a raceme. Fruit a capsule. Widely distributed $=$ Bog-bean (Menyanthes trifoliata). 


\section{CHAPTER V}

\section{PLANTS OF THE SEA COAST}

Of the species described below all are herbs except False Heather (Hudsonia tomentosa) which is a shrub. Most are perennial herbs but several members of the family Chenopodiaceae (namely Suaeda, Salicornia sp., Salsola Kali, and Chenopodium rubrum), Euphorbia polygonifolia, Spergularia, Cakile edentula, Gerardia maritima, and Aster subulatus are annuals.

Among the characteristics shown by this group of plants are the following:

1. In many of them the leaves are succulent or fleshy wth small intercellular spaces. This coridition occurs in Sea Purslane (Minuartia peploides), American Sea Rocket (Cakile edentula), and others.

2. The leaves are usually simple and entire. Sometimes they are quite small as in False Heather, while in Glasswort (Salicornica) they are almost absent and the succulent stem carries on the work of Photosynthesis.

3. Those species growing on sand have frequently long and branching rhizomes which enable them to hold their position where the sand is liable to drift. The formation of sand-dunes is due mainly to these species.

4. In some of the sand-loving species such as Marram Grass (Ammophila arenaria) the two edges of the leaf fold upwards until they meet thus diminishing greatly the amount of water lost by evaporation. Rolled leaves of this type occur in various other plants growing on dry situations.

5. A coating of wax also serves to reduce transpiration and is found in various species such as Sea Lyme-grass (Elymus arenarius) and Sea Lungwort (Mertensia maritima).

Some of the plants found on the sea coast also occur inland. Several of those growing on salt marshes occur on saline soil in the interior and a considerable number of those found on sand dunes also occur on the sands bordering the Great Lakes. There is a strong probability that some of these inland stations for such plants represent former coast lines on which the plants have survived as relics. While the similarity of habitat may account for the presence of some of the sand-loving species around the Great Lakes there is evidence to show that Lake Ontario and the St. Lawrence Valley were connected with the sea within a comparatively recent geological period.

There are three principal habitats on which halophytes or sea-coast plants are found, namely, mud or marsh, sand, and rocks or gravel.

\section{KEY TO CANADIAN SPECIES}

1. Plants growing on mud or salt marsh.. . . . . . . . . . . . . . . . . . . . . $\quad 2$

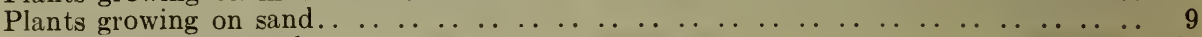

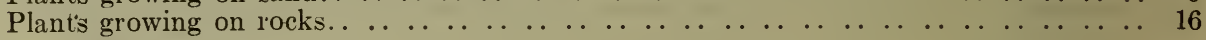

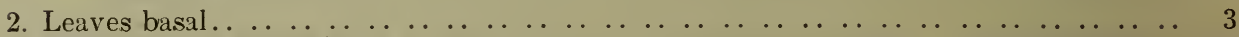

Leaves opposite, cauline. $\ldots \ldots \ldots \ldots \ldots \ldots \ldots$

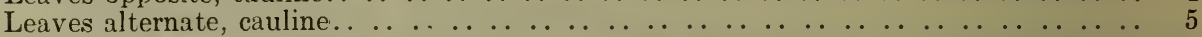

3. Leaves linear. Flowers in a long raceme, wind-pollinated, with six perianth segments, 6 stamens, and six united carpels. Occurs on both Atlantic and Pacific coasts and on saline soil in the interior = Sea Arrow-grass (Triglochin maritima).

Leaves flat and broad. Flowers in one-sided spikes which are grouped in a branching inflorescence. Petals purplish with the five stamens opposite to them. Fruit oneseeded, indehiscent. Occurs on the Atlantic coast $=$ Sea Lavender (Limonium carolinianum). 
Flowers in a spike, wind-pollinated. Petals four, united. Stamens four, with long filaments. Fruit a lid-capsule. Occurs on the Atlantic and Pacific coasts and on saline soil in the interior = Plantain (Plantago $s p$.).

4. The leaves are reduced to minute scales. The flowers occur in groups in the upper leaf-axils and are sunk into the tissue of the stem. Occurs on both eastern and western coasts and in the interior = Glasswort (Salicornia sp.).

Annual or biennial plants with fleshy leaves and scarious stipules. Flowers in a terminal cyme. Sepals five. Petals five. Styles three. Occurs on both coasts and in the interior = Sand Spurry $($ Spergularia $)$.

Perennial plants with linear or spatulate leaves and yellow flowers in solitary heads. Fruit without a tuft of hairs. Occurs on Vancouver Island=Yellow Jaumea (Jaumea carnosa).

Flowers solitary in the axils of the flattened leaves. There is a calyx of five purplish sepals but no corolla. Style single. Occurs on both eastern and western coasts and on saline soil in the interior = Sea Milkwort (Glaux maritima).

Annual plants with linear leaves. Petals united, rose-purple. Stamens 4. Nova Scotia only = Sea Gerardia (Gerardia maritima).

5. Flowers in spikelets, wind-pollinated.. . . . . . . . . . . . . . . . . .

Flowers in the axils of the leaves or occurring singly in a branched inflorescence, wind-pollinated.. . . . . . . . . . . . . . . . . . . . . . . . . . . . . . . 7

Flowers in a head or umbel, brighly coloured. . . . . . . . . . . . . . . . . . . 8

6. The spikelets are one-sided and are grouped along a common axis.' Eastern $=$ SaltMarsh Grass (Spartina sp.).

Spikelets in a contracted panicle. Each spikelet is one-flowered. Flowers hermaphrodite. Eastern = Dense-flowered Bent-grass (Agrostis maritima).

Plants dioecious. Inflorescence a spike-like panicle. Each spikelet contains several flowers. Occurs on the eastern and western coasts and on saline soil in the interior $=$ Spike-grass (Distichlis' spicata).

Stoloniferous plants with the spikelets in an open panicle. There are several flowers in each spikelet. Flowers hermaphrodite. Occurs on both eastern and western coasts = Sea Spear-grass (Glyceria maritima).

The flower has a single bract at its base. The perianth consists of bristles. Stigmas three. Fruit one-seeded and indehiscent, free from the subtending bract. On both eastern and western coasts $=$ Club-rush (Scirpus sp.).

7. Perennial tufted plants. Inflorescence branched. Perianth composed of six segments. Stamens six. Fruit a capsule with numerous seeds. Occurs on both eastern and western coasts = Black Grass (Juncus Gerardi).

Annual species with sessile leaves. Flowers axillary, solitary or clustered. Perianth composed of five segments. Stamens five. Fruit one-seeded, indehiscent. On the Atlantic coast $=$ Sea-blite (Suaeda $s p$.).

Perennial plants with the stipules united to form a sheath around the stem. Flowers in a branching panicle. Fruit one-seeded and indehiscent, surrounded by the persistent perianth. Occurs on the eastern coast = Large-tubercled Dock (Rumex pallidus).

8. Perennial creeping plants. The leaf consists of the hollow cylindrical jointed petiole. Inflorescence a few-flowered umbel. Flowers white. On Atlantic and Pacific coasts = Jointed Lilaeopsis (Lilaeopsis sp.).

Annual erect plants with narrow leaves and flowers in heads. Ray flowers purplish. It occurs on the eastern coast $=$ Annual Salt-marsh Aster (Aster subulatus).

Perennial erect plants with fleshy lanceolate leaves. Flowers yellow, in heads which are grouped on one side of the recurved branches. It is confined to the eastern coast = Sea Golden-rod (Solidago sempervirens).

9. Leaves lobed, divided or compound. . . . . . . . . . . . . . . . . . . . 10

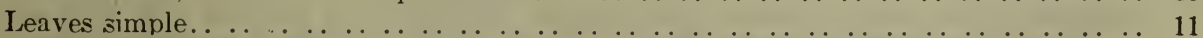

10. Leaves palmately compound, covered with silky hairs. Flowers in racemes. Corolla zygomorphic, blue in colour. Fruit a legume. It occurs on the western coast $=$ Chinook Licorice (Lupinus littoralis).

Leaves pinnately compound. Flowers in racemes. Corolla zygomorphic, purple. Fruit a legume. Occurs on both coasts and around the Great Lakes = Pea (Lathyrus sp.). 
Leaves ternately divided, covered with woolly hairs. Flowers white, grouped in umbels. Fruit separating into two one-seeded segments. Occurs on the western coast = Shore Glehnia (Glehnia littoralis).

Leaves pinnately divided. The staminate and pistillate flowers are in separate heads. The fruiting heads are covered with spines. Occurs on the western coast = Sandbur (Franseria bipinnatifida).

11. Leaves opposite. . . . . . . . . . . . . . . . . . . . . . . . 12

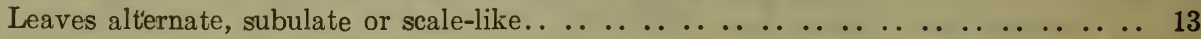

Leaves alternate, linear. . . . . . . . . . . . . . . . . . . . . . . . . . . . . . . 14

Leaves alternate, broad.. . . . . . . . . . . . . . . . . . . . . . . . . . . 15

12. Prostrate, annual monoecious plants with milky juice. Flowers in a cup-like inflorescence. Fruit three-celled, separating into three one-seeded segments. Occurs on the east coast and on the shores of the Great Lakes=Knotweed Spurge (Euphorbia polygonifolia).

Flowers with a brightly coloured calyx and no corolla. Fruit one-seeded and indehiscent. On western coast $=$ Sea Umbrella-wort (Abronia sp.).

Perennial plants with branching rhizomes and sessile fleshy leaves. Flowers solitary, in the axils of the leaves or forks of the stem. Sepals five. Petals five, white. Fruit a three-valved capsule with several seeds. On both eastern and western coasts = Sea purslane (Minuartia peploides).

13. Annual plants with the midrib of the leaf prolonged into a sharp point. The flowers are solitary in the axils of the leaves. Perianth composed of five segment's each of which develops a broad wing in fruit. The fruit is one-seeded and indehiscent. On eastern coast $=$ Prickly Saltwort (Salsola Kali).

Small downy shrubs with scale-like, imbricated, and appressed leaves. Petals five, yellow. Stamens numerous. On the eastern coast and on sandhills in the interior = False Heather (Hudsonia tomentosa).

14. Flowers in spikelets which are grouped in a dense panicle. Each spikelet is oneflowered. The rachilla is prolonged beyond the flower and bears a tuft of hairs. It occurs on the eastern coast and on the shores of the Great Lakes = Marram Grass (Ammophila arenaria).

Flowers in spikelets which occur in pairs and are attached directly to the central axis in a series of notiches. Each spikelet contains three or more flowers. It occurs on both eastern and western coasts and also on the shores of the Great Lakes = Sea Lyme Grass (Elymus arenarius).

Leaves rolled inwards. Flowers in a panicle, sometimes unisexual. There are several flowers in each spikelet. Western coast= Sand Spear-grass (Poa $s p$.$) .$

Spikelets clustered, forming a dense head. Some plants bear staminate heads only. There is only one flower in the axil of each bract. Fruit enclosed in a swollen bract (perigynium). Western coast $=$ Sand Sedge. (Carex macrocephala).

Flowers in a dense cluster, apparently borne laterally on the stem but the apparent prolongation of the stem is a leaf. Flowers with a perianth of six segments and six stamens. Fruit a capsule with numerous seeds. Western coast=Sand Rush (Juncus Lesueurii).

15. Perennial plants with runners. Petals five, yellow. Stamens and carpels numerous. The fruit consists of achenes. It occurs on both coasts and on saline soil in the interior $=$ Seaside Crowfoot (Ranunculus Cymbalaria).

Annual plants with flowers in racemes. Petals four, purplish. The pod consists of two joints, each of which may contain one seed. It occurs on the eastern and western coasts and also around the Great Lakes = American Sea Rocket (Cakile edentula).

Annual erect plants with the flowers clustered in spikes. The flowers are pollinated by wind and have a single perianth. Fruit one-seeded and indehiscent. It occurs on both coasts and also on saline soil in the interior = Red Goosefoot (Chenopodium rubrum).

Perennial plants with glaucous; entire leaves. Flowers in a raceme, with leafy bracts. Petals five, united, blue to white in colour. Fruit four-lobed, separating when ripe into four one-seeded segments. On eastern coast=Sea Lungwort (Mertensia maritima).

Perennial plants with trailing stems. There are two large bracts under the calyx. Corolla funnel-shaped, pinkish. Carpels two, united. Confined to the western coast $=$ Sea Bindweed (Calystegia Soldanella). 
16. Annual or biennial herbs with alternate flat fleshy leaves and flowers in racemes. There are four free petals and six stamens. The pod is globose and two-celled. Found on the more northern parts of the east and west coasts = Scurvy-grass (Cochlearia $s p$.$) .$

Somewhat hairy plants with the leaves two or three times ternate and compound umbels of greenish-white flowers. The fruit is ellipsoid with a single vil-canal in each furrow. It occurs on the eastern coast=Sea Angelica (Coelopleurum actaeifolium).

Glabrous plants with aromatic roots, biternate leaves and compound umbels of white flowers. The leaves are fleshy. The fruit is oblong with two to three oil-canals in the furrows. It occurs on both coasts = Scottish Lovage (Ligusticum scoticum).

Leaves opposite. Flowers yellow, in heads which are about half an inch in diameter. It occurs on the western coast = Sea Baeria (Baeria maritima).

Tufted plants with basal linear leaves forming a rosette. Flowers pink. in apparent heads, but the order of development is not centripetal. There are five styles. It occurs on both coasts = Sea Pink (Statice Armeria).

Leaves alternate, woolly on the under side when young. Flowers yellow, in heads which are one and one-half to two inches in diameter. On both eastern and western coasts $=$ Sea Ragwort (Senecio Pseudo-Arnica). 


\section{CHAPTER VI}

\section{TREES}

A tree differs mainly from a herb in the fact that the stem persists for many years and forms an annual ring of wood each year on the outside of those previously formed. While there is no hard and fast line between a tree and a shrub a tree usually grows to a much greater height than a shrub and, when growing naturally, has only a single stem or trunk. Only those species which normally are large enough to be used for commercial purposes in this country will be considered in the present chapter. Trees exhibit a number of important adaptations to their surroundings some of which are considered below:-

1. During the winter the amount of sap present in the trunk and branches reaches a minimum. This is undoubtedly of great importance to the plant as the sap left, being more concentrated, can withstand a much lower temperature without freezing. In very cold weather freezing and splitting of the trunk may take place but the amount of injury produced is much less than would be the case if the stem contained the same amount of water as it holds during the summer months.

2. The softer growing parts of a tree occur at the tips of the twigs and below the outer bark of the trunk and branches, and these are the parts which are most liable to be injured by cold. The growing point at the end of a branch serves to promote extension in length and is protected in winter by the familiar bud-scales which fall off when growth is resumed in spring. Sometimes, as in Pine trees and in Tacamahac, there is present in addition a resinous or gummy secretion which serves still further to protect the young tissues within the bud. Under the bark of trees there is a layer of tissue which serves to increase the growth in girth. The outer bark of a tree consists of many layers of cells with corky cell-walls, and, as cork is impervious to water and is a bad conductor of heat and cold, it will be seen that the outer layers of bark protect the tree against cold in winter and the escape of sap travelling up to the leaves in summer. The presence of air inside the corky cells also serves as a protection against cold.

3. A tree with broad thin leaves growing in a country with a severe winter climate would be liable to be blown down by wind or to have its branchies broken off by the accumulation of snow. Winter conditions may be combatted in one of two ways.

In the evergreen trees, such as Pines and Spruces, the leaves are small, and more or less leathery in texture and well adapted to stand the rigors of winter. In the broad-leaved or deciduous trees certain vital processes known as the formation of an abscission layer take place towards the end of the growing season with the result that the leaves fall off leaving only bare twigs. A further provision of nature against winter in both evergreen and deciduous trees is found in the flexible nature of the smaller branches which bend easily before the wind or under the weight of superincumbent snow allowing it to fall off.

The Madroña (Arbutus Menziesii) a small tree occurring in the coast region of British Columbia has thick leathery leaves and is the only broad-leaved evergreen tree in Canada.

4. The great majority of the trees found in Canada are pollinated by wind. In such species the pollen is powdery and the pollen grains have no tendency to stick together as in the case of insect-pollinated plants. Sometimes, as in Pines, the pollen grain has a small balloon or air-sac attached to each side to give it further buoyancy. 
In such trees, moreover, the stigma is usually of the feathery type, thus offering a larger surface for the pollen grains to become attached to.

A still further aid in securing the pollination of sucis trees is found in the early flowering of some species such as the Poplars. Here the pollen is shed before the leaves unfold and in consequence has a much better chance to be blown through the bare twigs to the stigma of a pistillate flower. Moreover, as the pendent catkin sways in the wind the pollen is liable to be shaken out more readily.

5. Many species of trees have their seeds or fruits dispersed by the agency of wind. In some trees such as Poplars the seed is provided with a tuft of hairs while in Elms and others there is a wing-like extension which serves the same purpose. Fleshy fruits are of uncommon occurrence but are found in Sour Gum and in Black Cherry. Hooked fruits are unknown among Canadian trees.

6. Trees while growing in a state of nature deposit in process of time an accumulation of dead leaves and humus known as "duff" on the floor of the forest. Different species of fungi live among this leaf-mould and some of these become attached to the external surface of the tree-roots forming a feltwork of fungus-filaments surrounding the root and known as "Mycorhiza." As root-hairs are feebly developed in forest trces the mycorhiza absorbs water for the use of the tree in much the same manner as the root-hairs and appears to derive part of its nourishment from the external layer of the tree-root.

7. In some trees, such as Birch and White Spruce, the starch which has been formed in summer becomes transformed into fat during winter which in turn reverts to starch on the approach of spring. This formation of fat appears to be clearly an adaptation for withstanding the extreme cold of northern latitudes.

For purposes of identification trees may be divided into the two following groups.

I. Mostly evergreen trees, with resin-canals in many species, narrow or needle-like or scale-like leaves of firm texture, and seeds occurring between the scales of cones. (Larch is deciduous.)

II. Deciduous trees with broad thin leaves which fall off in autumn. The seeds do not occur in cones but in closed structures called fruits. (Madroña is evergreen.)

\section{KEY TO CANADIAN SPECIES}

1. Evergreen trees (except Larch) with cones. . . . . . . . . . . . . . . . . . . . . 2

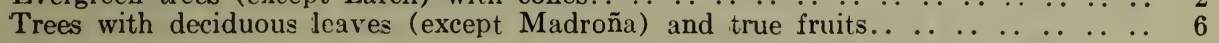

2. Foliage leaves linear, in tufts at the ends of dwarf shoots which are grouped along

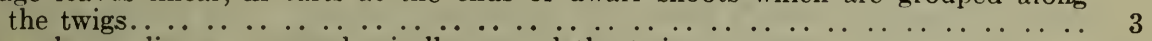

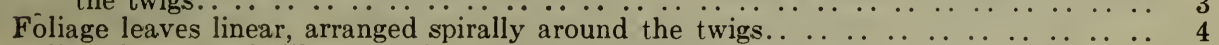

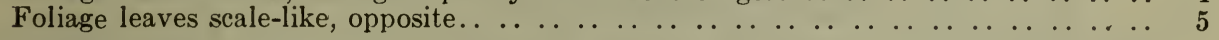

3. Leaves numerous on each dwarf shoot and deciduous. Widely distributed $=$ Larch (Larix).

Leaves two, three, or five on each dwarf shoot, persistent for several years. Widely distributed $=$ Pine (Pinus).

4. Leaves four-sided, attached to short persistent outgrowths of the twig, known as sterigmata. Cones pendulous, falling off entire. Widely distributed = Spruce (Picea).

Leaves flat, without sterigmata. Cones erect, breaking up and leaving only the central axis when ripe. Widely distributed = Fir (Abies).

Leaves flat, without sterigmata. Cones pendulous with a trifid scale under each seedbearing scale. Western = Douglas Fir (Pseudotsuga taxifolia).

Leaves flat, with short petioles attached to sterigmata. Cones pendulous. Eastern and Western $=$ Hemlock (T suga $)$. 
5. Bark shreddy. Cones ovoid with flat scales. Eastern and Western = Cedar (Thuja). Wood yellowish. Leaves with the points directed outwards. Cones globose with peltate scales. Occurs along the coast region of British Columbia $=$ Yellow Cypress (Chamaecyparis nootkatensis).

6. Leaves opposite. . . . . . . . . . . . . . . . . . . . . . . 7

Leaves alternate, pinnately compound..................... . . 8

Leaves alternate, simple. . . . . . . . . . . . . . . . . . . . . 9

7. Leaves bipinnate. Fruit a large legume, six inches long or more. Occurs only in Southern Ontario = Kentucky Coffee Tree (Gymnocladus dioica).

Leaves pinnately compound. Fruit one-seeded, indehiscent, winged. Eastern and Prairie Provinces = Ash (Fraxinus).

Leaves (except in Manitoba Maple) simple, palmately lobed. Fruit splitting when ripe into two segments each of which is provided with a wing. Widely distributed = Maple (Acer).

8. Pith of twigs brown, divided by transverse partitions. Leaves aromatic. Pericarp of fruit not splitting when ripe. Stone rugose or sculptured. Eastern = Butternut, and Walnut (Juglans).

Pith solid. Pericarp splitting into four valves. Stone smooth or angular. Eastern $=$ Hickory (Carya).

9. Plants dioecious. Fruit dehiscent, many-seeded. Seeds with a tuft of hairs. . . 10

Plants monoecious. Fruits one-seeded, indehiscent, covered by the overlapping scales

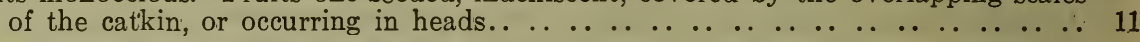

Plants monoecious. Fruits in groups of one to five, provided with a cupule or

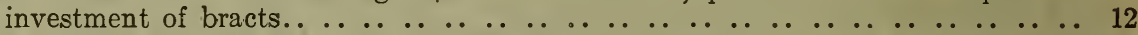

Flowers unisexual or hermaphrodite, with a perianth. Fruit fleshy or with a winged attachment.. . . . . . . . . . . . . . . . . . . . . . . . . . . . 13

10. The buds have a single bud-scale. The flowers have honey-glands. The bracts are entire. Eastern and Western $=$ Willow (Salix $s p$.).

The buds have several bud-scales. The bracts have a fringed or incised margin. Stamens mostly numerous. Widely distributed = Poplar (Populus).

11. Bark aromatic with transverse lenticels. The flower has two forked stamens. Bracts of the pistillate catkin deciduous with the fruits. Widely distributed $\stackrel{\text { Birch }}{=}$ (Betula sp.).

Bark astringent. Buds stalked. The flower has four stamens. The bracts of the pistillate catkin become woody and persist after the fruit falls off. Western = Alder (Alnus sp.).

Bark peeling off in flakes. Buds enclosed by the leaf-sheaths. Flowers in globular heads. Occurs only in Southern Ontario = Sycamore (platanus occidentalis).

12. The pistillate flower has two styles. The nut is enclosed in a large bladder-like bract. Eastern = Ironwood (Ostrya virginiana).

Bark smooth. Buds narrow and sharp-pointed. Staminate flowers in heads. The two three-sided nuts are enclosed in a cupule which splits into four valves when ripe. Eastern = Beech (Fagus grandifolia).

Leaves lanceolate, coarsely serrate, six inches long or more. The prickly cupule encloses two to three rounded nuts and splits into four segments when mature. Southern Ontario only $=$ Chestnut (Castanea dentata).

The cupule does not completely enclose the single rounded nut. Mostly eastern, but one species extends into the prairie and one species is confined to the coast region of British Columbia = Oak (Quercus).

13. Fruit dry when ripe... . . . . . . . . . . . . . . . . . . . . . . . 14

Fruit fleshy when ripe............................. 15

14. Flowers in small clusters, appearing mostly before the asymmetrical leaves. There is a single perianth. The fruit is one-seeded and winged. Eastern and Prairie = Elm (Ulmus).

Leaves pinnately veined with two basal and two terminal lobes, truncate or widely notched at the tip. Stipules large, enclosing the tip of the stem. Sepals three, petals three, stamens and carpels numerous. The winged fruits form an elongated cone. It occurs only in Southern Ontario= Tulip Tree (Liriodendron Tulipifera). 
The leaves are cordate. The inflorescence is attached to the middle of a large bract Fruit globose, dry, indehiscent. Eastern and Prairie = Basswood (Tilia americana).

15. Leaves with serrate margin. Fruit a globose, superior, one-seeded drupe. Eastern = Black Cherry (Prunus serotina).

Leaves with entire margin. Flowers unisexual. Fruit an ovoid inferior, one-seeded drupe. Confined to Southern Ontario = Black Gum (Nyssa sylvatica).

Bark dark red, peeling off. Leaves oval, entire, leathery. Fruit a globose orange-red berry. Western Coast region = Madroña (Arbutus Menziesii). 


\section{CHAPTER VII}

\section{PLANTS WITH PROTECTIVE DEVICES}

\section{Spiny Plan's}

One of the most effective methods of protection of the softer tissues of plants against grazing animals is that in which some part of the plant takes the form of a sharp thorn which pierces the skin of an animal coming into contact with it. The particular part of the plant forming the thorn varies in different species. In the Juniper it is the tip of the leaf, while in the Thistle it is the margin of the leaf. In the Rose stout prickles occur on the stem, whereas in the Hawthorn the long thorns probably represent a modified shoot.

In some species, such as Roses, the prickles doubtless have a second function, enabling the plant to climb by scrambling over the surface of other vegetation.

The chief spiny plants occurring in Canada are mentioned below.

\section{Plants with Stinging Hairs}

This is a small group of plants provided with stout pointed hairs which penetrate readily into the softer parts of animals and exude at the same time an irritating juice, producing a painful sensation. There are two genera of stinging plants, namely, Nettles and Wood Nettles, the characters of which are as follows:

Nettle (Urtica). Leaves opposite, stipulate. Flowers unisexual, with a perianth of four segments.

There are five Canadian species, two of which are widely distributed and three are western.

Wood Nettle (Laportea divaricata). Leaves alternate. Flowers unisexual, the staminate with a perianth of five segments, while the pistillate have a perianth of four segments. Eastern.

\section{Plants with a Disagreeable Taste or Odour}

A bitter taste is very characteristic of plants belonging to the Gientian family (Gentianaceae) such as the Bog Bean (Menyanthes trifoliata) and others.

A pungent or biting sensation is produced by the Toothwort (Dentaria), by Water Pepper (Polygonum Hydropiper), and by the various species of Onion (Allium). It is possible that in the last instance the characteristic odour makes the plant objectionable.

The disagreeable odour of the Skunk Cabbage (Symplocarpus foetidus) and of the Skunk Currant (Ribes glandulosum) and Skunk Bush (Rhus trilobata) doubtless renders these plants obnoxious to grazing animals. In the case of the first species, however, it is possible that the foul odour is intended to attract carrion flies and thus secure pollination of the flowers.

Mention should be made here also of those species which contain poisonous properties. It is also probable that the aromatic taste of some of the plants mentioned in the next chapter such as Wormwood protects them against grazing animals.

\section{KEY TO CANADIAN SPECIES OF SPINY PLANTS}

1. The spines are prolongations of the tip or the margin of the leaf .. $\ldots \ldots \ldots \ldots \ldots$

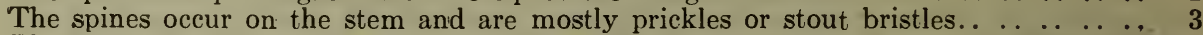

The spines are long thorns which in some cases are modified shoots. Shrubs or small trees. . . . . . . $\ldots \ldots \ldots \ldots \ldots \ldots$ 
2. Shrubs, with leaves in whorls of three. Tip of the leaf spiny. Seeds contained in a berry-like cone. Widely distributẹd=Common Juniper (Juniperus communis).

Annual herbs with the tip of the leaf prolonged into a spine. Flowers axillary. Perianth single, of five segments. Fruit one-seeded, indehiscent. Eastern sea coast $=$ Prickly Salitwort (Salsola Kali).

Shrubs with pinnately compound leaves, spiny along the margin, and yellow flowers. Fruit a bluish berry. Western = Oregon Grape (Mahonia).

Herbs with stipulate, pinnately compound leaves and spiny-tipped leaflets. Corolla zygomorphic. Fruit a legume. Occurs on the prairie only = Prickly Milk-vetch (Astragalus montanus').

Herbs. Leaves usually pinnately lobed, with spiny margins. Flowers in heads. Fruit one-seeded, with a tuft of hairs on the top. Widely distributed $=$ Thistle (Cirsium).

3. Leaves simple or absent. . . . . . . . . . . . . . . . . . . . . . . 4

Leaves compound. . . . . . . . . . . . . $\ldots \ldots \ldots \ldots \ldots$

4. Stem globose, without leaves but with tufts of needle-like spines. Petals numerous, purple. Stamens numerous. Occurs on the prairie only $=$ Purple Cactus (Mammillaria vivipara).

Stem divided into joints, with leaves on the younger parts only. Spines needle-like, in tufts. Petals numerous, yellow. Stamens numerous. Found in Southern Ontario, Prairie, and the West = Prickly Pear (Opuntia).

Shruibs with palmate leaves and flowers grouped in umbels on a terminal panicle. Ovary two-celled. Fruit a scarlet berry. Western = Devil's Club (Echinopanax horridum).

Shrubs with one to three spines at the nodes and sometimes stout bristles in addition on the stem. Leaves usually palmately lobed. Flowers mostly in racemes. Ovary one-celled. Widely distributed = Gooseberry and Currant (Ribes sp.).

Plants with tendrils at the base of the leaf = Greenbrier (Smilax $s p$.).

5. The fruit consists of achenes attached to the inside of the hollow, more or less globular fleshy receptacle. Widely distributed $=$ Rose $($ Rosa $)$.

The fruit consists of an aggregate of small drupes. Widely distributed $=$ Bramble (Rubus'sp.).

The leaves contain oil-glands. Flowers in clusters, borne on the twigs of the previous year and appearing before the leaves. Fruit dehiscent. Seed black and shining. Eastern = Prickly Ash (Zanthoxylum americanum).

6. The thorns are special organs and do not bear leares. The leaves are simple and often lobed. Carpels one to five, united with the receptacle as the fruit ripens. The sepals form a crown on the fruit which contains one to five stones. Widely distributed = Hawthorn (Cratacgus).

The tip of the twig becomes spiny. Leaves simple. Sepals deciduous. There is a single carpel which becomes a drupe with a single stone when ripe. Eastern $=$ Canada Plum (Prunus nigra).

Leaves pinnately compound. Thorns often trifid. The fruit is a large legume. Occurs in Southern Ontario = Honey Locust (Gleditsia triacanthos').

Leaves opposite with silvery scales on both sides. Plants dioecious. Perianth single, four-lobed. The fruit is an achene enclosed in the fleshy base of the perianth. Occurs on the prairie = Thorny Buffalo-Berry (Shepherdia argentea). 


\section{PLANTS CONTAINING RESIN, VOLATILE OILS, OR MILKY JUICE}

\section{Resiniferous Plants}

This group is exemplified in the Canadian Flora particularly by the Pine Family (Pinaceae). The resin is found in canals in the wood, bark, and leaves. Its use to the plant is not very clear but in case of a wound it flows out, solidifies, and covers over the wounded surface and in this way it may protect the plant to some extent against the attacks of injurious fungous diseases. The taste may also be a protection against animals.

Mention should perhaps be made here of the Gum-plant (Grindelia) in which the bracts under the flower-head secrete a gummy substance, of the Tacamahac (Populus balsamifera) with resinous buds, and of the Bog Myrtle (Myrica Gale) with resinous fruiting catkins.

\section{Aromatic Plants}

This group of plants is characterized by the presence of an agreeable odour which is due to the presence of volatile oil contained in the tissues. When the plant is crushed or broken the oil evaporates into the air making its presence readily felt. Some of these oils have a pungent or bitter taste and so their function in the plant's economy may in part be protective. No mention is made here of the scent of flowers which is intended to attract insects and thus secure cross-pollination. In the family Umbelliferae the oil is contained in special canals in the fruit. In Hypericum and the families Rutaceae and Magnoliaceae, the oil is contained in rounded cavities. These appear as small translucent dots when the leaf is held up to the light and viewed with a lens. In other cases the volatile oil occurs specially in the roots or rhizomes, or in the bark, or in the leaves. The following are the more important aromatic plants in the Canadian Flora:-

1. Aromatic roots occur in Balsam-root (Balsamorhiza), Sweet Cicely (Washingtonia), and Scottish Lovage (Ligusticum scoticurv) and the genera Aralia and Panax.

2. Aromatic rhizomes are found in Wild Ginger (Asarum canadense) and Vanilla Leaf (Achlys triphylla).

3. Aromatic bark occurs in the Yellow Birch (Betula lutea), the Red Elm (Ulmus fulva), and the family Magnoliaceae.

4. Aromatic leaves are found in Holy Grass (Hierochloë odorata); Sweet Flag (Acorus Calamus); in the families Juglandaceae, Myricaceae, Lauraceae, Magnoliaceae, and Rutaceae; Vanilla Leaf (Achlys triphylla); St. John's Wort (Hypericum); Fragrant Sumac (Rhus crenata); Checkerberry (Gaultheria procumbens); many species belonging to the family Labiatae; Musk (Mimulus moschatus); Wormwood (Artemisia); and Tansy (Tanacetum).

5. Aromatic fruits occur in many species of Umbelliferae.

\section{iII. Plants with Miıky of Coloured Juice}

The younger tissues of many plants contain a whitish fluid known as latex. It is contained in special tubes forming a network which are usually distributed throughout the plant from roots to leaves. In some members of the family Papaveraceae such as Blood Root (Sanguinaria canadensis) the latex is of an 
orange-red colour. The function of latex is still obscure. In some plants it may serve the purpose of a water reservoir. In the different species of Spurge (Euphorbia) it is more or less poisononus. Owing to its power of coagulating on exposure to the air it may serve to protect wounded surfaces.

In the Canadian Flora latex occurs in the following plants:-

Red Mulberry (Morus rubra), Sumac (Rhus), Spurge (Euphorbia), the families Papaveraceae, Apocynaceae, Asclepiadaceae, Convolvulaceae, Campanulaceae, Lobeliaceae, and Cichoriaceae. 


\section{CHAPTER IX}

\section{PLANTS DISPERSED BY WIND}

by wind.

There are four principal methods by which seeds and fruits are dispersed

I. The stem of the plant breaks off near the ground and the whole plant is blown about scattering its seeds as it goes. This occurs in Tumble Weed (Amarantus graecizans), Prairie Tumble-graiss (Schedonnardus paniculatus), and Old Witch Grass (Panicum capillare).

II. The seeds are extremely small and light. This occurs in the various species of Rush (Juncus), and in the families Orchidaceae and Orobanchaceae.

III. The seed or fruit has in connection with it a wing-like expansion. This method is exemplified more especially by tall plants such as trees. The particular part of the plant which forms the wing, varies greatly in different species.

(a) The wing is part of the seed in many species of the family Pinaceae and also in Wild Yam-root (Dioscorea villosa), the Trumpet Creeper (Tecoma radicans), and Yellow Rattle (Rhinanthus Crista-galli).

(b) The wing is an outgrowth or expansion of the wall of the fruit. This occurs in the following trees and shrubs: Most species of Alder (Alnus), Birch (Betula), Elm (Ulmus), 'Tulip Tree (Liriodendron Tulipifera). Hop Tree (Ptelea trifoliata), Maple (Accr), and Ash (Fraxinus). In the Maple the fruit has a double wing and splits into two one-seeded segments when ripe. Winged fruits also occur in the Mountain Sorrel (Oxyria digyna) and in some genera belonging to the family Umbellifercie such as Angeiica, Lomatium, and Heracleum.

(c) The wing is the enlarged perianth which encloses the fruit, as in some species of Dock (Rumex), or it is the calyx, as in Sea Pink (Statice Armeria).

(d) The wing is derived from a bract. In the Blue Beech (Carpinus caroliniana) the bract is leaf-like and three-lobed and is attached at the base of the nut. In the Ironwood (Ostrya virginiana) the bract becomes tubular and encloses the nut. In the Basswood (Tilia americana) the stalk bearing the cluster of fruits springs from the middle of the large flat bract.

IV. There is a series of hairs in connection with the seed or fruit which act like a parachute and enable the seed to be carried considerable distances before touching the ground. While the result is the same in the end there is considerable variation in the origin and method of attachment of the hairs. In some cases they are attached to the seed while in others they occur on the fruit.

(a) The hairs are attached to the seed.

In the family Salicaceae they are attached at the base; in Willow Heri (Epilobium) and the families Apocynaceae and Asclepiadaceae they are attached at the top; while in Wild Potato Vine (Ipomoea pandurata) they are attached around the margin.

(b) The hairs occur on the persistent and elongated style.

This condition is found in both species of Pasque Flower (Anemone patens and A. occidentalis), in Virgin's Bower (Clematis), in Prairie Smoke (Geum ciliatum), and mountain Avens (Dryas).

(c) The hairs represent the calyx or the perianth.

This occurs in the Cotton-grass (Eriophorum) where the hairs are attached at the base of the fruit; also in Valerian (Valeriana) and many species belonging to the families Cichoriaceae and Carduaceae in which they are attached at the top.

(d) The hairs are attached to the flower-stalk or some subsidiary structure. In the Cat-tail (Typha) the hairs are attached to the flower-stalk, whereas in the two genera of Reed-grasses namely Calamagrostis and Phragmites the hairs are attached to the rachilla. 


\section{CHAPTER X}

\section{PLANTS DISPERSED BY ANIMALS}

There are two important methods by which seeds of plants may be scattered over a wider area by animal agency. One is by the provision of a hook or series of hooks by which the seed or fruit becomes attached to the hair of a passing animal. In the other case the fruit is fleshy and is eaten by birds. The seed is enclosed in a hard covering which protects it from being crushed or injured by the digestive juices and it has the power of germination after passing through the animal's body. In this way the seed may be carried a long distance from the parent plant. Fleshy fruits are usually brightly coloured so as to be easily seen.

\section{Plants with Hooks in Connection with the Fruit}

As in the case of winged fruits there is also considerable diversity not only in the structure of the hook itself but also in the particular part of the plant which bears it. There are at least 3 different types of hook found in Canadian species.

(1) The hooked arrangement consists of a stout bristle or prickle which is curved at the tip. This occurs in Sanicle. (Sanicula) and many other plants.

(2) The hooked structure consists of a rigid bristle or awn with a series of downwardly directed barbs along its sides. This occurs in the various species of Beggar-ticks (Bidens).

(3) The hooked structure consists of a central shaft with a series of recurved hooks at the end like the flukes of an anchor. This is found in Hound's Tongue (Cynoglossum).

The principal plants in the Canadian flora provided with hooks for seed dispersal are as follows:-

(a) The hooks are stout prickles on the bracts enclosing the fruit. Occurs in Clotbur (Xanthium).

(b) The hooks are stout prickles on the floral receptacle. Found in Agrimony (Agrimonia).

(c) The 3 hooks are modified calyx-teeth. Occurs in Lopseed (Phryma leptostachya).

(d) The hook is derived from the persistent style as in Hooked Crowfoot (Ranunculus recurvatus). Sometimes the style has a zig-zag bend when young, but as the fruit develops the style becomes rigid and the terminal part breaks off leaving a hook. This occurs in various species of Avens (Geum).

(e) The hooks take the form of stiff, straight, backwardly directed hairs or barbs arranged around a central axis. Found on the fruit of Beggar-ticks (Bidens) and Sweet Cicely (Washingtonia).

$(f)$ The hooks consist of numerous stout prickles attached to the fruit. Occurs in Wild Licorice (Glycyrrhiza lepidota), Sanicle (Sanicula), and Forked Stickseed (Ctenospermum penicillatum).

(g) The hooks are bristles or hairs on the fruit in Tick-trefoil (Desmodium), Enchanter's Nightshade (Circaea), Hedge-parsley (Caucalis microcarpa), and some species of Bedstraw (Galium).

(h) Grappling hooks of anchor type occur in the Dwarf Wild Carrot (Daucus pusillus), Stickseed (Lappula), and Hound's Tongue (Cynoglossum). 


\section{Plants with Fleshy Fruits or Seeds}

In this group the fruit has usually a pleasant taste, is generally brightly coloured and sometimes has an attractive odour. In a few cases which will be mentioned below the fleshy part is not strictly a part of the fruit but may be derived from the seed or perianth.

In most cases the fruit when ripe is smooth but in some species of Sumac (Rhus) it is hairy, while in various species of Gooseberry (Ribes) it may be bristly. In many cases, such as Blueberry (Vaccinium) and Grape (Vitis) it is covered with a deposit of wax forming a "bloom."

Fleshy fruits are usually brightly coloured, the commonest types being shades of red and purple. The so-called black colours of fruits are in reality a very deep purple.

The fruits of Madroña (Arbutus Menziesii) and of Horse Gentian (Triosteum aurantiacum) are orange-red; those of May Apple (Podophyllum peltatum) and of White-leaved Honeysuckle (Lonicera Sullivantii) are yellow. The fruit of Arrow Arum (Peltandra virginica) is green while in Poison Ivy (Rhus Toxicodendron) it is greenish-white. Fruits of a white colour are rare, but are found in White Baneberry (Actaea alba), Snowberry (Symphoricarpos), and Creeping Snowberry (Chiogenes hispidula). Fleshy fruits and seeds are numerous in Canada. A list of the more important is given below.

\section{A. Gymnosperms.}

In the Ground Hemlock (Taxus canadensis) and Western Yew (T. brevifolia) there is a red fleshy cup-shaped aril at the base of the seed. The Junipers (Juniperus) have a globose cone resembling a berry which looks as if it were intended to be eaten by birds.

\section{B. Monocotyledons.}

Fleshy fruits in this group occur in Frog's Bit (Limnobium Spongia), in which it is inferior; in the family Araceae in which the fruit is frequently sunk into the tissue of the spadix; and in several genera of the family Liliaceae in which the fruit is superior. In this family blue or purple fruits occur in the genera Clintonia, Polygonatum, Medeola and Smilax, while red fruits are found in Smilacina, Maianthemum, Disporum, Streptopus, and Trillium.

\section{Dicotyledons.}

As there are many fleshy fruits belonging to this group they are here arranged for convenience of reference into a number of sections.

1. The ovaries of two flowers grow together into a fleshy mass which resembles a single fruit.

Twin-fuits of this kind occur in Partridge-berry (Mitchella repens) and Blue Fly-honeysuckle (Lonicera coerulea).

2. The perianth or calyx swells up and becomes fleshy enclosing the fruit which is dry. This occurs in the genera Morus, Elaeagnus, Shepherdia, and Gaultheria.

3. The fleshy fruit is enclosed in the enlarged calyx. Occurs in the genus Physalis.

4. The floral receptacle becomes fleshy while each of the separate carpels gives rise to a dry fruit. This condition is found in the genera $R o s a$ and Fragaria.

5. The carpels are separate and each gives rise to a single fleshy fruit. Occurs in the genera Asimina, Hydrastis, Rubus, and Dalibarda. 
6. Each flower develops a single fruit.

(a) Fruit one-seeded, superior. Occurs in the genera Celtis, Menispermum, Sassfras, Benzoin, Prunus, Rhus, Dirca.

(b) Fruit one-seeded, inferior. Occurs in Arceuthobium, Comandra, Nyssa, Viburnum.

(c) Fruit with several or many seeds, superior. Occurs in Phytolacca, Actaea, Podophyllum, Mahonia, Empetrum, Corema, Ilex, Nemopanthus, Rhamnus, Vitis, Arctostaphylos, Arbutus, Solanum.

(d) The fruit has several or more seeds and is inferior. Occurs in Ribes, Pyrus, Amelanchier, Crataegus, Araliaceae, Cornus, Vaccinaceae, Adoxa, Triosteum, Sambucus, Symphoricarpos, Lonicera.

7. The seed is fleshy.

In the Blue Cohosh (Caulophyllum thalictroides) the two seeds at an early stage of development burst the ovary and at maturity each of the blue seeds resembles a separate fruit.

In the Burning Bush (Euonymus atropurpureus) and the Staff Tree (Celastrus scandens) the fruit is a capsule but each seed is provided with a bright red fleshy aril which is attractive to birds. 


\section{CHAPTER XI}

\section{PRINCIPAL FAMILIES AND GENERA}

Of the 278 living families of Seed-plants enumerated in Engler's "Das Pflanzenreich", 125, that is less than one-half, occur in Canada.

There is great difference of opinion among botanists as to the limits of genera. This difference is shown by a comparison of such important works as Bentham and Hooker's "Genera Plantarum" and Engler and Prantl's "Die Natürlichen Pflanzenfamilien". If the conception of the genus which the authors of the former work have adopted be followed there are in Canada about 680 genera of aboriginal plants. This total is made up as follows: Gymnosperms, 10; Monocotyledons, 143; Dicotyledons, 527. Of this total 109. genera, or approximately one-sixth, contain shrubs or trees.

\section{LARGEST FAMILIES}

There are in the Canadian flora seventeen families, each of which contains ten or more genera. These with the number of genera included are as follows:-

Monocotyledons.

Gramineae, 54; Liliaceae, 25; Orchidaceae, 18; Cyperaceae, 12.

Dicotyledons.

Carduaceae, 65; Umbelliferae, 30; Rosaceae, 25; Cruciferae, 24; Sarophulariaceae, 22; Fabaceae, 21; Ranunculaccae, 17; Labiatae, 16; Ericaceae, 14; Boraginaceae, 14; Saxifragaceac, 13; Cichoriaceae, 13; Chenopodiaceae, 11 .

If the families Carduaceae, Cichoriaceae, and Ambrosiaceae be grouped together under Compositae, and the family Cassiaceae be grouped along with Fabaceae under Leguminosae, and if Vacciniaceae be included with Ericaceae, the number of genera will be as follows:-

Compositae, 83; Leguminosae, 24; Ericaceae, 18.

\section{FAMILIES MAINLY 'TROPICAL}

There are a number of families of plants in Canada whose headquarters are in tropical or warm countries but which have representatives extending into Canada. The majority of these are herbs, this manner of life tending to protect them from the extreme cold of winter under a blanket of snow. The shrubs and trees belonging to this group are confined to the region between the Lakes in Southern Ontario where the climate of winter is not so severe. The following are the families referred to:-

\section{A. Herbs.}

The following families are each represented by one genus in Canada: Eriocaulaceae, Dioscoreaceae, Podostemaceae, Melastomataceae, Apocynaceae, Acanthaceae.

The families Amaryllidaceae, Cactaceae, Asclepiadaceae, Verbenaceae, and Cucurbitaceae are each represented by two genera, while the family Araceae has six genera in Canada.

B. Shrubs or Trees.

The families Moraceae, Anonaceae, and Bignoniaceae are each represented by one genus, while the families Magnoliaceae and Lauraceae have each two genera. 


\section{LARGEST GENERA}

While there is considerable difference of opinion among botanists as to the exact limits of genera the problem of defining a species presents almost insuperable difficulties. Accordingly it seems best to regard the figures given below as only an approximation in each case.

There are in Canada about one hundred genera containing ten or more species. Twelve of these genera are shrubs or trees of which five genera belong to the family Rosaceae. Of the herbs by far the largest genus is Carex, which contains about two hundred and seventy-seven Canadian species.

Next in point of order are those genera which contain over 50 species. These are: Salix. 96; Aster, 84; Potentilla, 79; Saxifraga, 56; Ranunculus, 53;

Poa, 51; Solidago, 51; Polygonum, 51.

The genera containing from 40 to 50 species are: Astragalus, 49 ; Rubus, 49; Erigeron, 47; Juncus, 46; Viola, 46; Artemisia, 44; Senecio, 42.

The genera which contain 30 to 40 species are: Antennaria, 36; Epilobium, 36; Gentiana, 35; Rosa, 35; Panicum, 34; Arnica, 33; Minuartia, 32.

A considerable number of genera contain 20 to 30 species, namely: Arabis, 30 ; Draba, 30; Castilleja, 28; Lupinus, 28; Potamogeton, 27; Crataegus, 26 ; Habenaria, 26; Oenothera, 26; Anemone, 24; Deyeuxia, 24; Glyceria, 24; Oxytropis, 24; Pentstemon, 24; Scirpus, 24; Pedicularis, 23; Agrostis, 21; Elymus, 21; Festuca, 21; Ribes, 20. 


\section{CHAPTER XII}

\section{CLIMATE AND FLORAL REgIONS OF CANADA}

\section{Topography and Climatic Factors}

As the Dominion of Canada extends east and west for a distance of about 3,000 miles from the Atlantic to the Pacific ocean, and north and south from latitude 42 degrees to several degrees beyond the Arctic Circle, and as there are a considerable number of very large lakes in the interior while other parts of the country are almost desert-like in character, and as the eastern coasts are washed by cold currents coming from the north while on the western coasts the ocean currents travel from the south, and as there is every gradation in the height of the land surface from sea level to mount Logan with an altitude of 19,539 feet and perpetual snow and glaciers, it will be evident that there must of necessity be great diversity in the climatic conditions.

There are three principal elevated regions in Canada, namely, the Laurentian Highlands in the centre, the Appalachian range in the east, and the Cordilleras of Canada in the west. The Laurentian Highlands are shaped somewhat like the letter V; the point of the V lies on lake Ontario and the two limbs enclose Hudson bay between them. One limb forms the backbone of the province of Quebec, while the other is bounded on the west by lake Winnipeg, lake Athabaska, Great Slave lake, and Great Bear lake. The Laurentian Highlands are separated from the Appalachian range by the St. Lawrence valley, while on the west the great Central plain and the Mackenzie River valley intervene between them and the Cordilleras.

As a general rule the climate, unless where it is modified by the presence of large bodies of water, bears a direct relation to the distance from the equator and to the altitude above sea-level. Viewed in their relation to plant life the most important climatic factors are temperature, precipitation, and evaporation. Of less importance are wind, sunshine, and humidity.

\section{Temperature}

With the exception of a narrow belt along the coast of British Columbia the climate of the greater part of Canada is continental; that is, it exhibits a great annual range of temperature from the lowest temperature recorded in winter to the highest in summr. While Vancouver shows an annual range extending from 2 degrees in winter to 92 degrees F. in summer, the annual range at Winnipeg varies from -53 degrees $F$. to 103 degrees $F$.

The minimum temperature reached in winter is of great importance in determining the distribution of plants, more particularly in the case of shrubs and trees; herbaceous plants are often protected from the effects of severe cold by a covering of snow.

The actual maximum temperature reached at any point in Canada is of comparatively little significance in its effect on plant life, as these temperatures are seldom sufficiently high to be injurious unless they should happen to coincide with a period of severe drought. A better index to the amount of heat registered will be found in the mean temperature of the hottest month and in the number of days in each year on which the maximum temperature rises above 68 degrees.

The length of the period of active growth also throws an important light on the nature of the climate. The definition of the term "period of active growth "will vary considerably with the country in question and with the species of plant under consideration. While growth may take place slowly at lower 
temperatures, very little active growth is possible in Canada below a mean daily temperature of 41 degrees F. Accordingly the period of active growth is taken to mean that period which for every five days without exception shows a mean temperature of 41 degrees $\mathrm{F}$. or higher. The length of this period as well as other information on temperature will be found in the tables given further on.

\section{Precipttation}

Precipitation generally takes the form of rain in summer and of snow in winter. It reaches its greatest amount along the Pacific coast, followed next in order by the provinces bordering the Atlantic and by the region between the Great Lakes. It diminishes towards the interior, the driest regions occurring in the south of Saskatchewan and the dry belt in British Columbia.

The snowfall is important in several ways. On the higher mountains it forms glaciers and thus limits the upward extension of vegetation on their slopes; it cools the air in the vicinity of the glaciers in summer and as it melts feeds the rivers and maintains the water level during the period of greatest drought. On the lower grounds it forms an effective protection to the vegetation covered by it during the period of extreme cold in winter, and saturates the ground with moisture when it melts in spring.

Instead of giving the total rainfall for the year at any particular place it is considered to be more satisfactory to give the total amount which falls during the period of active growth only.

\section{Evaporation}

Hardly of less importance than the amount of rain which falls is the amount which disappears by evaporation from the surface of the ground. When rain falls on sloping ground a large amount of it may run off into the nearest stream. This is more likely to happen in the case of the torrential rainfall which usually follows a thunderstorm. On level ground the rain is gradually absorbed and much of it may sink down to depths which are beyond the reach of the roots of plants. The moisture in the upper layers when it is not absorbed by plants gradually passes into the air by evaporation. It thus appears that evaporation stands to rainfall in much the same relation as the two items in a profit and loss account.

Evaporation from a water surface is easily measured, but few observations have been made up to the present in Canada. Such observations as there are, however, show that on a particularly favourable day as much as one-sixth of an inch or more of water may pass into the air by evaporation.

The rate at which evaporation takes place varies largely even in the same locality, according to the nature of the soil, the temperature of the air, the intensity of the wind, the humidity of the atmosphere and the amount of sunshine. It is therefore a very important climatic factor. Evaporation from the floor of a forest is much less than from open ground.

The relation of rainfall to evaporation at Ottawa during the summer of 1920 can be seen from the following table:-

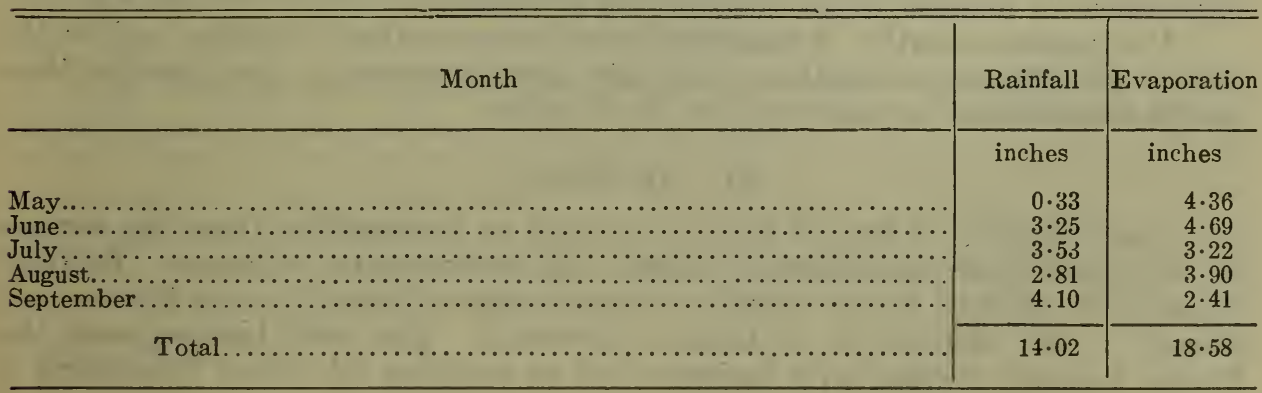


The following figures, which are taken from the Annual Reports of the Experimental Farms Branch of the Department of Agriculture, show the relation between rainfall and evaporation at three different points on the prairie during the summer months:-

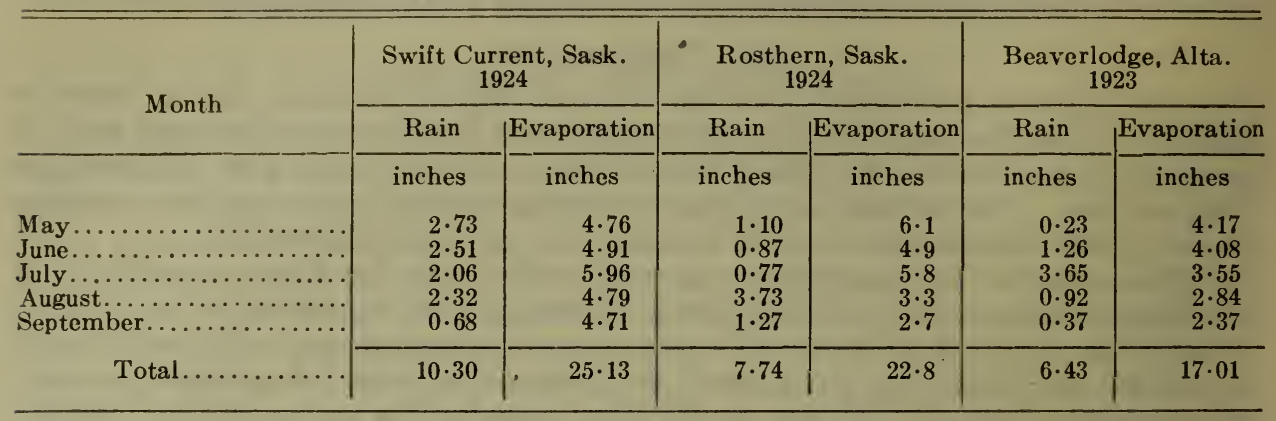

At Summerland, which is on the dry belt of British Columbia, the total evaporation from April 23 to October 31, 1922, was 28.54 inches, while the rainfall for the same period was 5.12 inches.

As few statistics are available to show the relative amounts of evaporation at various points in Canada, the length of the period of longest drought is given in the subjoined tables instead. During the period of active growth a rainfall of less than $\frac{1}{4}$ inch in one day is considered to have little effect on plants. Accordingly a drought period is taken to mean the number of days that elapse between a rainfall of $\frac{1}{4}$ inch in 24 hours and the next similar amount.

\section{WIND}

Wind is one of the lesser factors limiting the growth of plants. As mentioned above, it directly influences the rate of evaporation. It is also an important agent in effecting the pollination of many plants and in procuring the dispersal of their fruits when ripe. It also limits to some extent the duration of life of tall trees.

The wind, as a rule, blows with greatest force on the Atlantic and Pacific coasts, on the shores of the Great Lakes, and over the prairie.

\section{Sunshine}

Direct sunshine is of importance in promoting the photosynthetic proresses which go on in all green plants. But some plants, especially those found in the shade of a forest, appear to prefer a more subdued light, while others, especially those classed as xerophytes, are able to endure the brightest sunshine without injury. The amount of sunshine also affects the temperature of the air and soil and the rate of evaporation and thus it is an agent of considerable importance in relation to the distribution of plants.

It is perhaps worthy of mention that in more northern latitudes and on the tops of mountains the duration of sunlight during summer is much greater than on the lowlands or in places nearer the Equator.

\section{Humidity}

The humidity of the air acts as a check on evaporation from the surface of the ground and also from the leaves and other organs of plants. Relative humidity is greatest in the vicinity of large bodies of water and on the western slopes of the mountains of British Columbia. The wind blowing over the Pacific becomes charged with moisture but on reaching the Coast Mountains it 
is forced to ascend and becomes cooler until the saturation point is reached, when the excess moisture is deposited as rain. Passing over the mountains it descends, becomes warmer and reaches the dry belt as a dry wind. On reaching the still higher elevations of the Selkirks and Rocky Mountains it again parts with more moisture and reaches the eastern slopes of the mountains and the prairie as a quite dry wind.

The figures given further on for a number of localities in the different floral regions of Canada will give a fair idea of the nature of the climate. As, however, they are based on observations extending over four to eleven years they do not represent all the variations which may occur in process of time.

\section{Floral. Rrgions of Canada}

As the Dominion of Canada covers such a large territory, there may, and doubtless will be, considerable differences of opinion as to the various floral regions which may be recognized. Taking into account the topography, climate, and present distribution of plants there are, at any rate, six fairly well defined floral areas. These and their boundaries are as follows (see accompanying map) :-

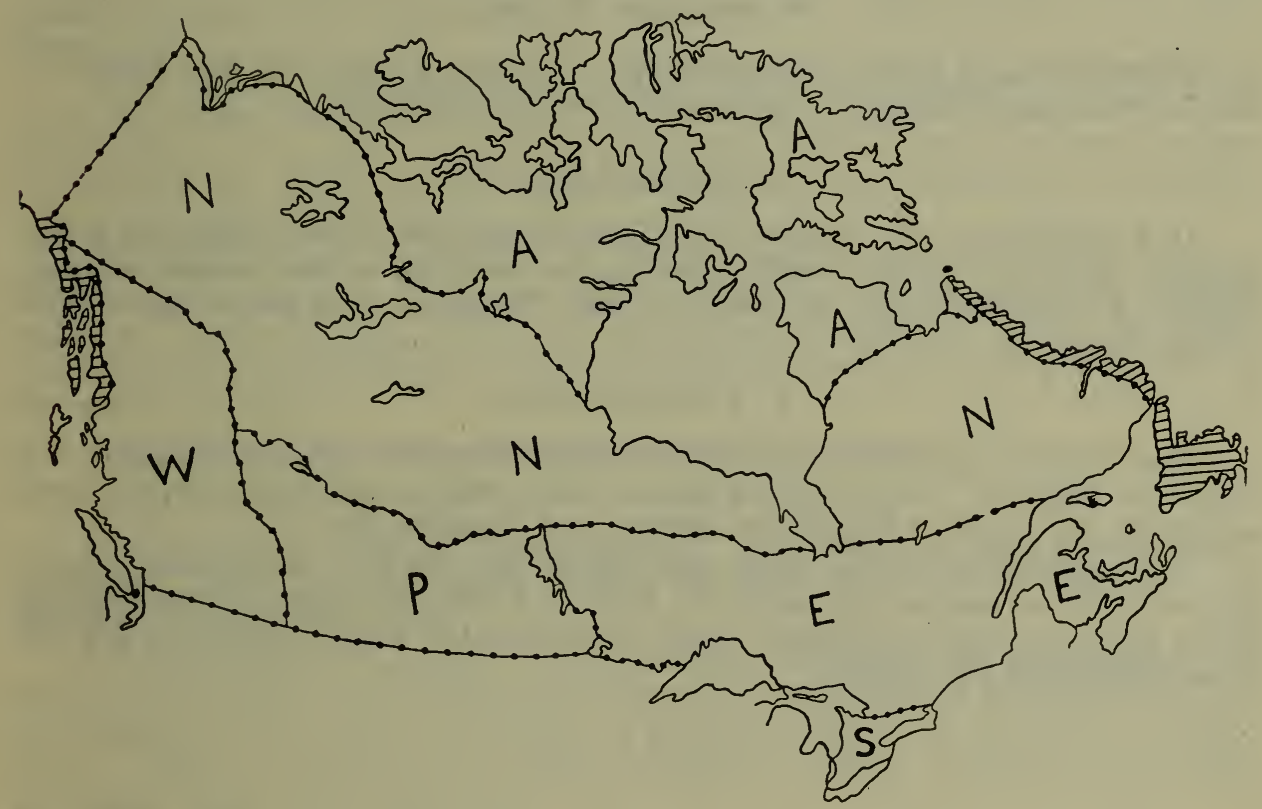

Map of floral regions of Canada-A, Arctic Region; N, Northern Region; E, Eastern Region; S, Southern Region; P, Prairie Region; W, Western Region. For boundaries see pages 41 and 42. The shaded areas on the Atlantic side comprise Newfoundland and Labrador while those on the Pacific coast are part of Alaska. (The boundary between Labrador and Quebec has been altered somewhat since this map was drawn.)

\section{Arctic Region}

This includes the area beyond the northern limit of tree growth, and is bounded for the most part by a line from Hebron in Labrador, to the mouth of the George River, through the mouth of the Leaf River and continued onwards until it reaches Hudson Bay. On the west side of Hudson Bay the boundary begins at Churchill, runs to the south end of Dubawnt Lake, through Lake Mackay, west end of Coronation Gulf, south end of Franklin Bay, to the mouth of the Mackenzie River, from which it is continued nearly parallel to the coast. to the boundary of Alaska. 


\section{Norithern Region}

The Northern or Transcontinental Region is bounded on the north by the Arctic Region; on the south by a line drawn from the most northerly point of Anticosti Island, through Lake Mistassini, Moose Factory on James' Bay, Norway House at north end of Lake Winnipeg, The'Pas, Saskatchewan River to Prince Albert, Beaver River, Athabaska Landing, Athabaska River, Lesser Slave Lake, Peace River Landing, Peace River to near Fort St. John, Pine River, Fort Nelson River, Liard River up to Lower Post, southern boundary of Yukon; on the west by the boundary between Yukon and Alaska.

\section{Eastern Region}

It is bounded by the Northern Region on the north and by a line drawn from Kingston to Collingwood on the south. West of Lake Superior the line follows the international boundary to Lake of the Woods, Winnipeg River, and Lake Winnipeg to Norway House.

On the north the boundary is mainly the northern limit of White Cedar and Mountain Maple.

\section{Southern Region}

It includes that part of the Province of Ontario lying south and west of a line drawn from Kingston to Collingwood on Georgian Bay.

\section{Prairie Region}

It is bounded by the Eastern and Northern Regions on two sides, the international boundary on the south, and on the west by a line drawn through Pincher, Cochrane, Rocky Mountain House, Parkgate, and Peace River east of Fort St. John.

\section{Western Region}

The Western or Cordilieran Region includes the area west of the Prairie and Northern Regions. The southern part of this region is bounded on the east mainly by the limit of Engelmann Spruce and Douglas Fir.

The boundaries of the above six regions can be best understood from a glance at the accompanying map. As there is a certain amount of overlapping of the Floras of any two regions where they meet, the above boundaries are not to be interpreted too rigidly. 


\section{CHAPTER XIII}

\section{ARCTIC REGION}

While the growing season is short and the lower strata of the soil remain permanently frozen it would be a mistake to suppose that this region is devoid of plant life. While high temperatures are not reached the period of daylight is very extended. Stefansson in describing the Canadian Arctic Expedition, writes as follows:-

"The highest latitude reached by the expedition was eighty degrees north, where the summer lasted three and one half to four months, and the sun shone day and night. It is quite a mistaken notion to imagine that these islands we visited are always covered with ice, and that it is always bitter cold. The climate, as a fact, fifty to one hundred miles inland is very similar to the Orkneys and some northern parts of Scotland, though on the coast it is generally colder, because of the proximity of the ocean ice. The winter is long and bitter."

Many species of plants survive in arctic climates as may be seen by reference to works dealing with these regions. In the report by Macoun and Holm of the Botany of the Canadian Arctic Expedition 1913-1918 no less than two hundred and twenty-five species of seed-plants belonging to one hundred and ten genera and representing thirty-six families are mentioned.

The families best represented in Arctic America generally are Graminece, Cyperaceœ, Composito, Cruciferce, Caryophyllacee, Saxifragaceœ, and Ranunculacece. The prevalence of Grasses and Sedges is doubtless due to the better facilities for wind-pollination in these regions as compared with pollination by the agency of insects.

Some of the more outstanding features of Arctic Plants are:-

1. The absence of trees.

2. The small number of annual species. As pollination is so uncertain the perennial habit is an advantage. Arctic Gentian (Gentiana arctophila) is an example of the annual type.

3. Tufted habit of growth. This is due to branching and shortness of the internodes. This cushion-like form is doubtless a protection against wind, and may partly be due to the retardation of growth in length by the long continued light. This is exemplified by Moss Campion (Silene acaulis) and Arctic Diapensia (Diapensia lapporica).

4. Trailing habit of growth. This occurs in Crowberry (Empetrum nigrum) and Trailing Azalea (Loiseleuria procumbens).

5. Xerophytic characters or adaptations to diminish transpiration are well marked. The leaves are leathery in Loiseleuria procumbens, rolled in Empetrum nigrum, hairy in Draba and Alpine Chickweed (Cerastium alpinum), covered with wax in Long-leaved Arctic Willow (Salix glauca).

6. The colours of the flowers are deeper.

7. Vivipary sometimes occurs, that is, a small plant develops in place of a flower and strikes root when it falls on the ground. This condition occurs in Serpent Grass (Polygonum viviparum), and Sheep's Fescue (Festuca ovina).

8. Thorny plants are almost entirely absent. region.

9. Climbing plants, parasitic and saprophytic plants do not occur in this 
Five genera, namely, Bartsia, Chrysanthemum, Eutrema, Lagotis, and Parrya, are in Canada confined to the Arctic Region.

There are many species of Arctic Plants which do not occur outside that region. Among these may be mentioned Arctic Wild Rye (Elymus mollis), Arctic Dock (Rumex arcticus), Arctic Scurvy-grass (Cochlearia groenlandica), Arctic Loco-weed (Oxytropis arctobia), Arctic Shooting Star (Dodecatheon frigidım), Arctic Primrose (Primula stricta), Arctic Lousewort (Pedicularis capitata), and Arctic Ragwort (Senecio frigidus).

There is another group of plants, mainly Arctic in their distribution, which are found also on the higher slopes of the mountains south of that region where the climatic conditions are equally rigorous. Some are shrubs such as Netveined Willow (Salix reticulata), Entire-leaved Mountain Avens (Dryas integrifolia), Narrow-leaved Labrador Tea (Ledum palustre), Dwarf Rhododendron (Rhododendron lapponicum), Trailing Azalea (Loiseleuria procumbens), and Channel-leaved Cassiope (Cassiope tetragona).

Among the herbs belonging to this group are Arctic Cotton-grass (Eriophorum Scheuchzeri), Mountain Sorrel (Oxyria digyna), Moss Campion (Silene acaulis), Nodding Campion (Lychnis apetala), Arctic Crowfoot (Ranunculus affinis), Iceland Poppy (Papaver nudicaule), Purple Saxifrage (Saxifraga oppositifolia), Snowy Cinquefoil (Potentilla nivea), Arctic Wintergreen (Pyrola grandiflora), and Arctic Harebell (Campanula uniflora). 


\section{CH'APTER XIV}

\section{NORTHERN REGION}

The highest elevation in this region east of Hudson Bay occurs at Lake Tshinikoman in Quebec, where an altitude of 2,980 feet is attained. The land on both sides of Hudson Bay is comparatively low, while in the west high mountains occur in Yukon Territory in the southwest corner of which Mount Logan is situated. Great Slave Lake is 520 feet above sea-level.

Some indication of the climate in different parts of this region may be obtained from a study of the subjoined table.

\begin{tabular}{|c|c|c|c|c|c|c|}
\hline Place & $\begin{array}{l}\text { Mistassini, } \\
\text { Que. }\end{array}$ & $\begin{array}{l}\text { Port } \\
\text { Nelson, } \\
\text { Man. }\end{array}$ & $\begin{array}{l}\text { Le Pas, } \\
\text { Man. }\end{array}$ & $\begin{array}{c}\text { Fort } \\
\text { Vermilion, } \\
\text { Alta. }\end{array}$ & $\begin{array}{c}\text { Fort } \\
\text { Good Hope } \\
\text { N.W.T. }\end{array}$ & $\begin{array}{l}\text { Dawson } \\
\text { Y.T. }\end{array}$ \\
\hline Altitude (feet). & 360 & 49 & 860 & & 214 & 1,075 \\
\hline Mean temperature of hottest & $61 \cdot 1-68 \cdot 0$ & $54-59$ & $60 \cdot 0-69 \cdot 5$ & $56 \cdot 0-62 \cdot 5$ & $53 \cdot 5-61 \cdot 0$ & $56 \cdot 5-62 \cdot 6$ \\
\hline $\begin{array}{c}\text { Number of days above } 68 \\
\text { degrees, } F \ldots \ldots \ldots \ldots\end{array}$ & & 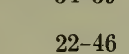 & $62-106$ & & 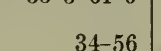 & 8000 \\
\hline $\begin{array}{l}\text { Absolute minimum temper- } \\
\text { ature, F................ }\end{array}$ & -49 & -52 & -54 & -78 & -79 & -63 \\
\hline $\begin{array}{l}\text { Length of period of active } \\
\text { growth (days) ............ }\end{array}$ & & $81-134$ & $116-157$ & & 109-136 & $115-147$ \\
\hline $\begin{array}{l}\text { Rainfall during period of } \\
\text { active growth (inches) }\end{array}$ & & $5 \cdot 0-10 \cdot 8$ & $7 \cdot 0-12 \cdot 7$ & & $3 \cdot 2-5 \cdot 2$ & $4 \cdot 7-8 \cdot 9$ \\
\hline $\begin{array}{l}\text { Duration of longest drought } \\
\text { (days) ........ }\end{array}$ & & $10-54$ & $21-37$ & & & $23-61$ \\
\hline 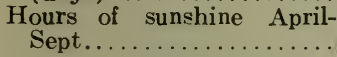 & $1,110-1,286$ & & $1,130-1,461$ & $1,269-1,729$ & & \\
\hline
\end{tabular}

This region occupies a transitional position between the Arctic region on one side and the Eastern and Western regions on the other. Its flora is largely a mixture of the species found to the north and south of it. Few species in Canada are absolutely confined to this region, one of these being the Small White Water Lily (Nymphaea tetragona).

The forests form the most conspicuous element in the Flora. The following trees extend all across the continent and reach their northern limit in this region: Black Spruce (Picea mariana), White Spruce (Picea canadensis), Tamarack (Larix laricina), Paper Birch (Betula alba), American Aspen (Populus tremuloides), Balsam Poplar (Populus balsamifera), Jack Pine (Pinus Banksiana), Balsam Fir (Abies balsamea). Some trees whose headquarters are in the Western region extend into Yukon and mingle with the Northern forest. These are the Lodgepole Pine (Pinus contorta), Alpine Fir (Abies lasiocarpa), Alaska Birch (Betula alaskana), Mountain Alder (Alnus tenuifolia), and Longleaf Willow (Salix fuviatilis).

Of shrubs the following are the most characteristic: Common Juniper (Juniperus communis), Creeping Juniper (Juniperus horizontalis), Scrub Birch (Betula glandulosa), Smooth Buffalo Berry (Shepherdia canadensis), Swamp Red Currant (Ribes triste), Shrubby Cinquefoil (Potentilla fruiticosa), Black Twinberry (Lonicera involucrata).

The Heath Family in the broad sense is represented by five species of shrubs and undershrubs, namely: Bearberry (Arctostaphylos Uva-Ursi), Wild Rosemary (Andromeda Polifolia), Creeping Snowberry (Chiogenes hispidula), Dwarf Bilberry (Vaccinium caespitosum), Bog Bilberry (Vaccinium uliginosum.) 
There is a large number of herbs which have a transcontinental range. Many of these occur in the eastern region and also on the mountains of British Columbia, but they do not extend across the prairie.

Rather more than half the transcontinental species of herbs belong to the group of Monocotyledons. Some of the most characteristic species are the following: Marsh Arrow-grass (Triglochin palustris), Lesser Duckweed (Lemna minor), Tall Cotton-grass (Eriophorum angustifolium), Tufted Hair-grass (Deschampsia caespitosa), Holy Grass (Hierochloë odorata), Floating Pondweed (Potamogeton natans), Clasping-leaved Twisted-stalk (Streptopus amplexifolius), Early Coral Root (Corallorrhiza trifida), Lesser Rattlesnake Plantain (Peramium ophioides).

The Dicotyledons are represented by the following species: Strawberry Blite (Blitum capitatum), Three-leaved Gold Thread (Coptis trifolia), Northern Stitchwort (Stellaria borealis), Kidney-leaved Violet (Viola renifolia), Northern Grass of Parnassus (Parnassia palustris), Fire-weed (Epilobium angustifolium), Bunch-berry (Cornus canadensis), One-flowered Wintergreen (Pyrola uniflora), Narrow-leaved Cow-wheat (Melampyrum lineare), Marsh Speedwell (Veronica scutellata), Northern Bedstraw (Galium boreale), Twin-flower (Linnaea americana). 


\section{CHAPTER XV}

\section{EASTERN REGION}

The lighest elevations in this region are North Cape Summit in Nova Scotia, which is 1,500 feet, Mount Carleton in New Brunswick, which is 2,630 feet, and Table Top Mountain in the Gaspe Peninsula, which is 4,000 feet above the sea and is the highest point of the Appalachian Range in Canada.

Tip-top Hill lies near the western shore of Lake Superior, reaches an altitude of 2,120 feet, and is the highest point of the Laurentian Highlands in Ontario.

Lake Winnipeg is 710 feet above sea level, while Lake Superior is 602 feet above the sea.

The nature of the climate at different points throughout the region is shown in the following table:-

\begin{tabular}{|c|c|c|c|c|c|c|c|}
\hline Place & $\begin{array}{l}\text { Halifax, } \\
\text { N.S. }\end{array}$ & $\begin{array}{l}\text { Wolfville, } \\
\text { N.S. }\end{array}$ & $\begin{array}{c}\text { Frederic- } \\
\text { ton, } \\
\text { N.B. }\end{array}$ & $\begin{array}{c}\text { Quebec } \\
\text { City, } \\
\text { Que. }\end{array}$ & $\begin{array}{l}\text { Ottawa, } \\
\text { Ont. }\end{array}$ & $\begin{array}{c}\text { Hailey- } \\
\text { bury, } \\
\text { Ont. }\end{array}$ & $\begin{array}{c}\text { White } \\
\text { River, } \\
\text { Ont. }\end{array}$ \\
\hline Altitude (feet) ............ & 88 & 135 & 164 & 296 & 234 & 687 & 1,244 \\
\hline 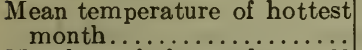 & $63 \cdot 5-68 \cdot 7$ & $62 \cdot 7-70 \cdot 0$ & $63 \cdot 7-70 \cdot 4$ & $65 \cdot 1-70 \cdot 5$ & $58 \cdot 8-73 \cdot 5$ & $61 \cdot 3-71 \cdot 5$ & $55-65$ \\
\hline $\begin{array}{r}\text { Number of days above } 68 \\
\text { degrees } F \ldots \ldots \ldots \ldots \ldots\end{array}$ & $63-92$ & & $87-95$ & $75-98$ & $99-117$ & $73-98$ & $53-95$ \\
\hline $\begin{array}{l}\text { Absolute minimum tempera- } \\
\text { ture, } \mathrm{F} \ldots \ldots \ldots \ldots\end{array}$ & -17 & -16 & -35 & -34 & -32 & -48 & -60 \\
\hline $\begin{array}{l}\text { Length of period of active } \\
\text { growth (days) } \ldots \ldots \ldots \ldots \ldots\end{array}$ & $178-212$ & & $177-185$ & $158-189$ & $177-198$ & $155-167$ & $131-144$ \\
\hline $\begin{array}{l}\text { Rainfall during period of } \\
\text { active growth (inches) }\end{array}$ & $19 \cdot 0-31 \cdot 5$ & & $20 \cdot 1-28 \cdot 8$ & $16 \cdot 4-35 \cdot 5$ & $16 \cdot 0-25 \cdot 0$ & $13 \cdot 5-22 \cdot 0$ & $12 \cdot 3-14 \cdot 8$ \\
\hline $\begin{array}{l}\text { Duration of longest drought } \\
\text { (days) } \ldots \ldots \ldots \ldots \ldots \ldots \ldots\end{array}$ & $15-36$ & & $17-31$ & $15-33$ & $22-36$ & & $25-41$ \\
\hline $\begin{array}{c}\text { Hours of sunshine, April- } \\
\text { Sept..................... }\end{array}$ & & $1,071-1,325$ & $1,055-1,353$ & $968-1,350$ & $1,310-1,587$ & $\mid, 119-1,472$ & \\
\hline
\end{tabular}

With a few exceptions Lake Winnipeg forms a very distinct boundary to the eastern flora of Canada. While these few exceptions extend for some distance west of the Lake they have their headquarters in the country lying to the east of it. Most of the genera and species of plants mentioned below extend also through the Southern Region into the Eastern United States.

Of the Families of plants occurring in Canada there are fourteen which are confined in their distribution to the eastern half of the country. These with the genera included in them are as follows:-

MoNocotyledons.

Eriocaulaceae (Eriocaulon); Pontederiaceae (Heteranthera, Pontederia); Xyridaceae (Xyris).

DicotYledons.

Acanthaceae (Dianthera); Thymelaeaceae (Dirca); Hamamelidaceae (Hamamelis); Ilicaceae (Ilex, Nemopanthus); Juglandaceae (Carya, Juglans); Menispermaceae (Menispermum); Phrymaceae (Phryma); Podostemaceae (Podostemum); Rutaceae (Zanthoxylum); Staphyleaceae (Staphylea); 'Tiliaceae (Tilia).

In addition to the above seventeen genera there are fifty-nine others confined to the eastern half of the Dominion. These are:- 


\section{Monocotyledons.}

The Family Araceae includes Acorus, Arisaema, and Symplocarpus; Gramineae is represented by Ammophila, Brachyelytrum, Milium, and Zizania; Liliaceae includes Aletris, Medeola, Polygonatum, and Uvularia; while Orchidaceae includes Arethusa, Calopogon, and Pogonia. Four other genera of Monocotyledons are Cladium, Lophiola, Lophotocarpus, and Vallisneria.

\section{DiCOTYLEDONS.}

The Family Leguminosae includes Amphicarpaea, Glycine, Phaseolus, and Tephrosia; Berberidaceae includes Caulophyllum and Podophyllum; Cistaceae. includes Helianthemum and Lechea; Betulaceae includes Carpinus and Ostrya; Gentianaceae includes Bartonia and Nymphoides; Labiatae includes Blephilia, Collinsonia, Isanthus, and Pycnanthemum; Rubiaceae includes Cephalanthus and Mitchella; Urticaceae includes Boehmeria, Laportea, and Pilea.

The other genera of Dicotyledons are Acalypha, Acnida, Adlumia, Anychia, Corema, Cryptotaenia, Epiphegus, Fagus, Floerkea, Gaylussacia, Littorella, Panax, Penthorum, Proserpinaca, Salsola, Sanguinaria, Sicyos, Triosteum, and Waldsteinia.

The species which in Canada are confined to the eastern region are much too numerous to describe at length. In addition to those already referred to under families and genera some of the more important species are as follows:-

\section{Trees}

Evergreen trees are represented by White Pine (Pinus Strobus), Red Pine (Pinus resinosa), Pitch Pine (Pinus rigida), Eastern Hemlock (Tsuga canadensis), and Eastern Cedar (Thuja occidentalis).

The deciduous trees include Yellow Birch (Betula lutea), White Oak (Quercus alba), Red Oak (Quercus rubra), Red Elm (Ulmus fulva), Rock Elm (Ulmus Thomasi), Sugar Maple (Acer Saccharum), Silver Maple (Acer saccharinum), Red Maple (Accr rubrum), Black Cherry (Prunus serotina), White Ash (Fraxinus americana), Black Ash (Fraxinus nigra).

White Pine is the largest tree in Eastern Canada and may occasionally attain a height of 250 feet and a diameter of six feet.

\section{SHRUBS}

Among the commoner species are the following:-Ground Hemlock (Taxus canadensis), Hackberry (Celtis occidentalis), White Virgin's Bower (Clematis virginiana), Staff Tree (Celastrus scandens), Blue-berried Grape (Vitis vulpina). Staghorn Sumac (Rhus hirta), New Jersey Tea (Ceanothus americanus), Prickly-fruited Gooseberry (Ribes Cynosbati), Sand Cherry (Prunus pumila), Ninebark (Physocarpus opulifolius), Smooth Chokeberry (Pyrus melanocarpa), Purple Thimbleberry (Rubus odoratus), Woolly Steeple-bush (Spiraea tomentosa), Silky Cornel (Cornus Amomum), Mountain Laurel (Kalmia latifolia), Rhodora (Rhododendron canadense), Smooth-leaved Honeysuckle (Lonicera dioica), Nannyberry (Viburnum Lentago), Hobble-bush (Viburnum alnifolium).

\section{Herbs}

Some of the commoner or more striking species are the following:-

(a) Water and Marsh Plants.

Water-weed (Elodea canadensis), Purple-fringed Orchid (Habenaria psychodes), Drooping Ladies'-tresses (Spiranthes cernua), Closed Gentian (Gentiana Andrewsii), Turtle Head (Chelone glabra), Square-stemmed Monkey Flower (Mimulus ringens), Purple-stemmed aster (Aster puniceus), Golden Ragwort (Senecio aureus). 
(b) Plants growing on open ground.

White Vervain (Verbena urticifolia) and Bluets (Houstonia coerulea).

(c) Plants growing in the forest.

As might be expected many herbaceous species are found in woods. Some of these with the families to which they belong are:-Liliaceae includes Yellow Clintonia (Clintonia borealis), Yellow Adder's Tongue (Erythronium americanum), Hairy Solomon's Seal (Polygonatum biflorum), Large-flowered WakeRobin (Trillium grandiflorum); Ranunculaceae includes White Baneberry (Actaea alba), Liver-leaf (Anemone Hepatica), Hooked Crowfoot (Ranunculus recurvatus); Fumariaceae includes Dutchman's Breeches (Dicentra cucullaria), Squirrel Corn (Dicentra canadensis); Saxifragaceae includes Two-leaved Mitrewort (Mitella diphylla), False Mitrewort (Tiarella cordiffolia) ; Carduaceae includes Blue Wood Aster (Aster cordifolius), Broad-leaved Golden Rod (Solidago flexicaulis).

In addition to the above the following are also characteristic of forests:Downy Rattlesnake Plantrin (Peramium pubescens), Wild Ginger (Asarum canadense), Two-leaved Toothwort (Dentaria diphylla), Smooth Yellow Violet (Viola eriocarpa), Spotted Cranesbill (Geranium maculatum); White Avens (Geum canadense), Enchanter's Nightshade (Circaea 'lutetiana), American Spikenard (Aralia racemosa), Hairy Sweet Cicely (Washingtonia Claytoni), Round-leaved American Wintergreen (Pyrola americana), Crosswort (Lysimachia quadrifolia), Wild Blue Phlox (Phlox divaricata), Tall Rattlesnake-root (Prenanthes trifoliolata). 


\section{SOUTHERN REGION}

The highest elevation in this region occurs at Dundalk Station in Grey County, which is 1,705 feet above the sea. Lake Ontario is only 246 feet above sea level.

Owing to its proximity to the Great Lakes this region has a shorter and milder winter than the territory to the north of it.

The climate at three points within the region is shown below:-

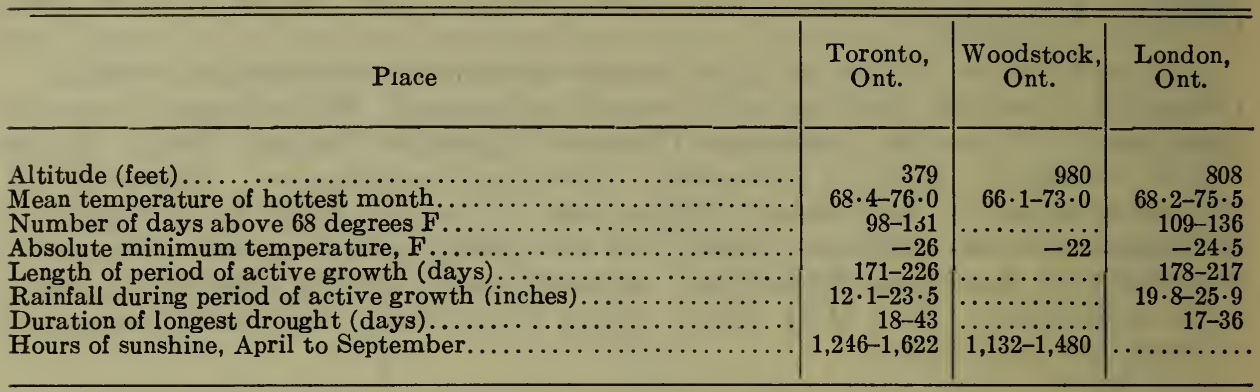

Although this region occupies a comparatively small area when compared with the other five, nevertheless it has a very distinctive flora which is doubtless due in a large measure to its geographical position between the Great Lakes and their effect on the climate.

There are eleven families found in this region which do not occur elsewhere in Canada. These families with the genera contained in them are as follows:-

Dioscoreaceae (Dioscorea); Saururaceae (Saururus); Moraceae (Morus); Anonaceae (Asimina); Magnoliaceae (Liriodendron, Magnolia); Phytolaccaceae (Phytolacca) ; Lauraceae (Benzoin, Sassafras) ; Platanaceae (Platanus) ; Cassiaceae (Cercis, Gleditsia, Gymnocladus) ; Melastomataceae (Rhexia) ; Bignoniaceae (Tecoma).

In addition to the fifteen genera mentioned above there are thirty-two others peculiar to this region. These are as follows:

\section{MoNocotyledons.}

The family Gramineae includes Cenchrus and Triplasis; Cyperaceae includes Fimbristylis, and Scleria; the other genera are Chamaelirium, Echinodorus, Limnobium, Peltandra, and Wolffia.

\section{DiCOTYLEDONS.}

The family Fabaceae includes Baptisia and Lespedeza; Umbelliferae includes Chaerophyllum and Erigenia; Carduaceae includes Mikania, Polymnia, and Silphium; Scrophulariaceae includes Buchnera and Conobea. The other genera are Calceolaria, Castanea, Euonymus, Frasera, Gillenia, Hibiscus, Ipomoea, Isopyrum, Jeffersonia, Lippia, Nelumbo, Nesaea, Nyssa, and Ptelea.

Some of the species confined to this region are as follows: Trees are represented by Black Walnut (Juglans nigra), Mockernut Hickory (Carya alba), Pignut Hickory (Carya glabra), Black Oak (Quercus velutina), Scarlet Oak (Quercus coccinea), and Blue Ash (Fraxinus quadrangulata). 
Among the shrubs are Bristly Greenbrier (Smilax hispida), Poison Sumac (Rhus Vernix), Pink-flowered Crab-apple (Pyrus glaucescens), Woolly-leaved Grape (Vitis aestivalis), Flowering Dogwood (Cornus florida), and Deerberry (Vaccinium stamineum).

Among the numerous herbs confined to this region are White Adder's Tongue (Erythronium albidum), Yellow Fringed Orchid (Habenaria ciliaris), Flowering Spurge (Euphorbia corollata), Perennial Lupin (Lupinus perennis), Smoothfruited Prickly Pear (Opuntia humifusa), Butterfly-weed (Asclepias tuberosa), Broad-leaved Water-leaf (Hydrophyllum canadense), Wild Bergamot (Monarda fistulosa), Dense Button-snakeroot (Liatris spicata), Tall Ironweed (Vernonia altissima). 


\section{CHAPTER XVII}

\section{PRAIRIE REGION}

This region consists of three belts running in a north-westerly direction from the international boundary to the North Saskatchewan river. The ground rises gradually from about 750 feet in the Red River Valley to about 4,500 feet in the foothills of the Rocky Mountains. In various parts of the region are lakes with no outlet, the water in which is alkaline.

The characteristic features of this region are low annual precipitation, prevalent winds, and a high percentage of sunshine. The soil of the prairie is usually deep. The roots of some plants such as Purple Skeleton Weed (Lygodesmia juncea) may penetrate to a depth of seven feet.

The climatic features of three different points on the prairie are as follows:-

\begin{tabular}{|c|c|c|c|}
\hline Place & $\begin{array}{c}\text { Winnipeg } \\
\text { Man. }\end{array}$ & $\begin{array}{l}\text { Qu'Appelle, } \\
\text { Sask. }\end{array}$ & $\begin{array}{l}\text { Edmonton } \\
\text { Alta. }\end{array}$ \\
\hline 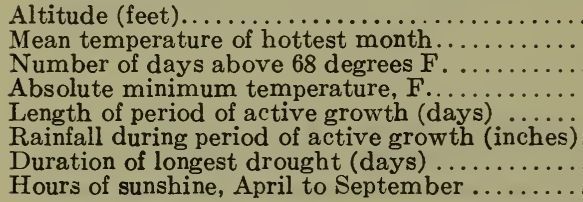 & $\begin{array}{r}760 \\
65 \cdot 2-72 \cdot 2 \\
87-125 \\
-53 \\
138-187 \\
9 \cdot 1-17 \cdot 8 \\
20-57 \\
1,147-1,543\end{array}$ & $\begin{array}{r}2,115 \\
57 \cdot 1-69 \cdot 5 \\
69-108 \\
-50 \\
143-173 \\
7 \cdot 9-17 \cdot 8 \\
22-55 \\
1,421-1,735\end{array}$ & $\begin{array}{r}2,158 \\
60 \cdot 0-65 \cdot 4 \\
70-106 \\
-57 \\
143-202 \\
8 \cdot 1-19 \cdot 7 \\
19-67 \\
1,327-1,578\end{array}$ \\
\hline
\end{tabular}

While the typical prairie is treeless-except along the river valleys-there is a transitional belt of mixed prairie and woodland along the eastern and northern sides. In marked contradistinction to the Eastern and Southern Regions there is no family of plants confined in Canada to the Prairie Region. The number of genera which occur only on the prairie is also much reduced, amounting to 15 altogether. There are, however, about 267 species characteristic of the prairie and not occurring elsewhere, about half of which are included under the three families of Composites, Leguminous Plants, and Grasses.

A characteristic feature of certain parts of the Prairie Region is the presence of lakes with no outlet around the margin of which the soil is saline or alkaline. In such localities plants occur which elsewhere are found on the sea coast, such as Spike Grass (Distichlis spicata), Sea Crowfoot (Ranunculus Cymbalaria), Sea Milkwort (Glaux maritima) and others.

On the dry prairie a marked feature of the vegetation is the abundance of xerophytes, that is, plants with adaptations calculated to counteract the loss of water from the plant by evaporation. As examples the following species, which are confined in their distribution to the Prairie Region, may be mentioned. Among shrubby types the Winter Fat (Eurotia lanata) has a dense covering of hairs, while the Thorny Buffalo Berry (Shepherdia argentea) has scales on the leaves. Of the herbaceous types the Hoary Sage-Brush (Artemisia cana) is covered with hairs; the Beard-tongue (Pentstemon nitidus) is glaucous; the Purple Skeleton-weed (Lygodesmia juncea) has the leaves much reduced in size; while in the purple Cactus (Marmmillaria vivipara) the stem is fleshy and leaves are absent altogether. As mentioned above some of the prairie plants are deep-rooting and are thus enabled to withstand a period of drought. 
The fifteen genera which are confined to the Prairie Region are as follows:-

The family Gramineae includes Buchloë, Munroa, and Schedonnardus; the family Fabaceae includes Amorpha, Petalostemon, and Thermopsis; the family Carluaceae includes Actinea, Gutierrezia, Hymenopappus, and Thelespermina; while the other genera are Eurotia, Paronychia, Mammillaria, Musineon, and Heliotropium.

\section{Trees on the Prairie}

Only three species of trees appear to be confined to the Prairic Region, namely Lance-leaved Cottonwood (Populus acuminata), Narrow-leaved Cottonwood (Populus angustifolia), and Prairie Ash (Fraxinus campestris). The Nianitoba Maple (Acer Negundo) is not absolutely confined to the Prairie Region but extends across the border for some distance into the Eastern Region.

Three characteristic eastern species, namely, the White Elm (Ulmus americana), the Bur Oak (Quercus macrocarpa), the Mountain Maple (Acer spicatum) extend into the Prairie Region.

On the north those species mentioned in the preceding pages as characteristic of the Northern Region may occur but gradually die out as the true prairie is reached.

The only western species which extends into the Prairie Region is the Lodgepole Pine (Pinus contorta) which occurs on the Cypress Hills in Saskatchewan.

The absence of trees on the prairie has been attributed to several causes. One of these is the prevalence of grass fires during summer which would tend to destroy all woody types of vegetation. Another possible cause is a period of drought which would tend to prevent the successful establishment of seedling trees. A third and much more probable cause was the former prevalence of large herds of buffalo. Only herbaceous types of vegetation could be expected to survive successfully the constant cropping of grazing animals.

\section{Shrubs}

There are about sixteen species of shrubs confined to the Prairie Region. Some of these have already been mentioned. Among the others are Yellowflowered Current (Ribes aureum), Prairie Cherry (Prunus Besseyi) and Skunkbush (Rhus trilobata).

There are several other species of shrubs common in the Prairie Region which have a wide distribution in other regions such as the Silver-berry (Elœeagnus argentea), Meadow-sweet (Spirca latifolia), Wolf-berry (Symphoricarpos occidentalis).

\section{HERBS}

Of the numerous species which are confined to the Prairie Region only a few can be mentioned here. Among characteristic species are the following: Grama Grass (Bouteloua oligostachya), Hairy Umbrella-wort (Allionia hirsuta), Prairie Violet (Viola pedatifida), Low Bladder-pod (Lesquerella spatulata), Bigseed Dock (Rumex venosus), Prairie Cinquefoil (Potentilla bipinnatifida), Prairie Turnip (Psoralea esculenta), Scarlet Gaura (Gaurc coccinea), Prairie Lily (Mentzelia decapetala), Oval-leaved Milkweed (Asclepias ovalifolia), Western False-gromwell (Onosmodium occidentale), Downy Gentian (Gentiana puberula), Western Ragweed (Ambrosia psilostachya). 


\section{CHAPTER XVIII}

\section{WESTERN REGION}

This country has been described as consisting of a "sea of mountains," many of which are characterized by the presence of glaciers and perpetual snow. The eastern border is formed by the Rocky Mountains, which are bounded on the west by a trench 900 miles long traversed by the Kootenay, Columbia, Canoe, Fraser, Parsnip, Finlay and Kachika Rivers. Mount Robson, 13,068 feet, is the highest peak of the Rocky Mountains in Canada. Of the other mountain ranges the Selkirks are an important group, lying within the bend of the Columbia River. The highest peak, Mount Sir Sanford, attains an elevation of 11,590 feet.

The Coast Range occupies a belt extending inwards from the sea for about 125 miles, and running from the Fraser River to Alaska. Mount Tatlow, east of Chilko Lake, is 10,100 feet high. South of the Fraser River are the Cascade Mountains, which are continued into the State of Washington, U.S.A.

East of the Coast Range the Interior Plateau or Dry Belt of British Columbia occurs. The Okanagan, Kamloops, Ootsa, François, Babine, Tacla, and Stuart Lakes lie in this region. The river valleys are less than 2,000 feet above the sea, while the higher grounds vary from 3,000 to 6,000 feet above sea level.

The greater part of Vancouver Island is above the 1,000 -foot line. Victoria Peak, 7,484 feet, is the highest point.

The principal variations in the climate of this region may be seen in the accompanying table:-

\begin{tabular}{|c|c|c|c|c|}
\hline Place & $\begin{array}{l}\text { Banff, } \\
\text { Alta. }\end{array}$ & $\begin{array}{c}\text { Invermere, } \\
\text { B.C. }\end{array}$ & $\begin{array}{c}\text { Kamloops, } \\
\text { B.C. }\end{array}$ & $\begin{array}{l}\text { Vancouver, } \\
\text { B.C. }\end{array}$ \\
\hline 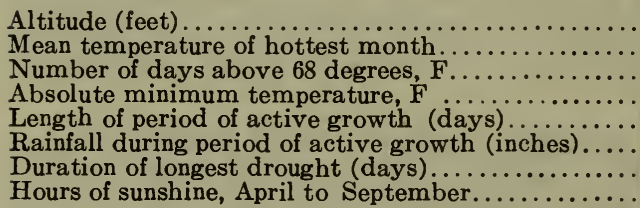 & $\begin{array}{r}4,521 \\
55 \cdot 8-60 \cdot 7 \\
50-76 \\
-47 \\
122-166 \\
5 \cdot 6-10 \cdot 4 \\
17-59 \\
\ldots . . .\end{array}$ & 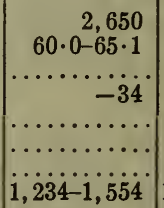 & $\begin{array}{r}1,262 \\
67 \cdot 3-71 \cdot 6 \\
114-140 \\
-31 \\
200-220 \\
4 \cdot 3-7 \cdot 3 \\
55-115 \\
1,303-1,645\end{array}$ & $\begin{array}{r}136 \\
60 \cdot 5-65 \cdot 6 \\
63-91 \\
-2 \\
225-256 \\
16 \cdot 0-34 \cdot 0 \\
38-52 \\
1,129-1,591\end{array}$ \\
\hline
\end{tabular}

The region extending from the Rocky Mountains to the Pacific coast exhibits within its area a greater diversity of climates than any other part of Canada. In consequence there are a number of well marked floral regions contained within it the most marked of which are the Coast Belt, the Dry Belt, and the Alpine Region.

The eastern boundary of the Coast Belt coincides almost with a line drawn through Princeton, North Bend, Hazelton, and the Head of the Portland Canal.

The Dry Belt has been described above. It includes the District from Okanagan Lake to Kamloops and beyond. There is also a smaller Dry Belt in the vicinity of Kootenay Lake.

The Alpine Region includes a large number of scattered areas above the timber line on the mountains. 
While there is no single family peculiar to the Western Region there are eighty genera which do not occur elsewhere in Canada. The number of characteristic species is very large.

The following genera are confined to the western region:-

GyMNOSPERMS.

There are two genera, namely Chamaecyparis and Pseudotsuga.

MoNocotyledons.

The family Potamogetonaceae includes Lilaea and Phyllospadix; the family Liliaceae includes the genera Brodiaea, Calochortus, Fritillaria, Rhabdocrinum, Stenanthium, and Xerophyllum. There is but one genus of Grasses confined to the west, namely, Melica, one genus of Iridaceae, namely, Tigridia, one genus of Araceae, namely Lysichiton, and one genus of Orchids, namely, Cephalanthera.

DiCOTYLEDONS.

The family Cruciferae includes Athysanus, Smelowskia and Thysanocarpus; the family Ranunculaceae includes Trautvetteria, and Trollius; the family Portulacaceae includes Lewisia and Talinum; the family Berberidaceae includes Achlys and Mahonia; the family Malvaceae includes Sidalcea and Sphaeralcea; the family Rosaceae includes Osmaronia and Purshia; the family Saxifragaceae includes Leptarrhena, Tolmiea, Philadelphus, and Tellima; the family Oenotheraceae includes Clarkia and Gayophytum; the family Umbelliferae includes Caucalis, Daucus, Eryngium, Glehnia, Leptotaenia, and Oenanthe; the family Ericaceae includes Arbutus, Cladothamnus, and Menziesia; the family Monotropaceae includes Allotropa and Hemitomes; the family Primulaceae includes Centunculus and Douglasia; the family Boraginaceae includes Amsinckia and Ctenospermum; the family Hydrophyllaceae includes Nemophila and Romanzoffia; the family Polemoniaceae includes Collomia and Microsteris; the family Carduaceae includes fifteen genera, namely Adenocaulon, Baeria, Blepharipappus, Brickellia, Chaenactis, Crocidium, Eriophyllum, Helianthella, Hemizonella, Layia, Luina, Psilocarphus, Sericocarpus, Tetradymia, and Wyethia; the family Cichoriaceae includes Apargidium, Microseris, and Stephanomeria.

The remaining genera of Dicotyledons are Echinopanax, Hosackia, Limnanthes, Pachystima, Platystigma, Bolelia, Boschniakia, Micromeria, Nicotiana, and Valerianella.

In considering the species which are confined to the western region it will tend to a clearer understanding of their destribution to divide them into four groups: (1) Species generally distributed; (2) Species confined to the coast belt; (3) Species characteristic of the dry belt; (4) Alpine species.

\section{Species Generally Distributed}

TREES

A few trees of Northern distribution extend into the Western Region the chief of which are the White Spruce (Picea canadensis), the Black Spruce (Picea mariana), the Tamarack (Larix laricina), and the American Aspen (Populus tremuloides).

The following species are more or less widely distributed, at any rate over the southern part of this region: Lodgepole Pine (Pinus contorta), Western White Pine (Pinus monticola), Lowland Fir (Abies grandis), Douglas Fir (Pseudotsuga taxifolia), Western Cedar (Thuja plicata), Western Hemlock (Tsuga heterophylla), Black Hemlock (Tsuga Mertensiana), Black Cottonwood (Populus trichocarpa).

Englemann Spruce (Picea Englemanni) occurs in the area lying to the east of the Coast Belt while Western Larch (Larix occidentalis) is confined to the southeast of British Columbia. 
Of these trees the largest in Canada are the Douglas Fir and Western Cedar. The former averages 180 feet in height with a diameter of three to four feet but may occasionally reach a height of 250 feet and a diameter of six to nine feet. The Western Cedar reaches a height of 175 feet and a diameter of ten feet or even more.

The following species occur on the mountains up to the timber line: Alpine Fir (Abies lasiocarpa), Alpine Larch (Larix Lyallii), Whitebark Pine (Pinus albicaulis), Limber Pine (Pinus flexilis).

\section{SHRUBS}

The following shrubs have a fairly wide distribution in the Western Region: Oregon Grape (Mahonia Aquifolium) Thimbleberry (Rubus parviflorus), Greenleaved Service Berry (Amelanchier Cusickii), Buck-brush (Ceanothus sanguineris), Devil's Club (Echinopanax horridum), Tall Mountain Bilberry (Vaccinium membranaceum), Wax-berried Elder (Sambucus glauca).

\section{HERBS}

Some species which are more or less widely distributed over the Western Region are: Skunk Cabbage (Lysichiton camtschatcense), Large-flowered Adder's Tongue (Erythronium grandiflorum), Western Wake-robin (Trillium ovatum), Western Wild Ginger (Asarum caudatum), Western Yellow Water-Lily (Nymphozanthus polysepalus), Foam Flower (Tiarella rinifoliata).

\section{Species Confined to the Coast Belt}

\section{TREES}

A considerable number of species are confined to the Coast Belt. The most important of these are: Yellow Cypress (Chamœcyparis nootkatensis), Sitka Spruce (Picea sitchensis), Amabilis Fir (Abies amabilis), Red Alder (Alnus oregona), Garry Oak (Quercus Garryana), Broad-leaved Maple (Acer macrophyllum), Cascara Sagrada (Rhamnus Purshiana), Western Dogwood (Cornus Nuttallii), Madroña (Arbutus Menziesii).

\section{SHRUBS}

Among the species that are confined to the Coast Belt are the following: Sitka Willow (Salix sitchensis), Rough-fruited Western Gooseberry (Ribes Lobbii), Smooth-fruited Western Gooseberry (Ribes divaricatum), Skunk Black Currant (Ribes bracteosum), Red-flowered Currant (Ribes sanguineum), Indian Plum (Osmaronia cerasiformis), Salmon Berry (Rubus spectabilis), Whiteflowered Crab-apple (Pyrus diversifolia), Salal (Gaultheria Shallon), Tall Bilberry (Vaccinium ovalifolium), Red Bilberry (Vaccinium parvifolium).

\section{HERBS}

Of the herbs which are characteristic of the Coast Belt some which occur on the sea shore have been mentioned already in Chapter V. Additional species are:-

Western Marsh Marigold (Caltha asarifolia), Western Buttercup (Ranunculus occidentalis), Cut-leaved Gold Thread (Coptis asplenifolia), Vanilla Leaf (Achlys triphylla), Many-flowered Dutchman's Breeches (Dicentra formosa), Blue Violet (Viola Langsdorfii), Three-leaved Coolwort (Tiarella trifoliata), Cut-leaved Coolwort (Tiarella laciniata), Water Parsley (Oenanthe sarmentosa), Deer Cabbage (Menyanthes Crista-galli), Swamp Hedge Nettle (Stachys ciliata). 
Species Characteristic of the Dry Belt

TREES

On the dry belt the only characteristic tree is the Western Yellow Pine (Pinus ponderosa).

\section{SHRUBS}

Few shrubby species are confined to the dry belt, the chief being Antelope Brush (Purshia tridentata), Twin-fruited Ninebark (Physocarpus malvaceus), and Sage-brush (Artemisia tridentata).

\section{HERBS}

As the Dry Belt has a very low rainfall the charactertistic plants of this area are mostly xerophytes. Some of these are:-

Bunch Grass (Agropyron spicatum), Two species of Umbrella-plant (Eriogonum), Rock Pink (Talinum spinescens), Bitter Root (Lewisia rediviva), Bladder-Pod (Lesquerella Douglasii), Thick-leaved Buttercup (Ranunculus glaberrimus), Four species of Stick-leaf (Mentzelia), Four species of Rattle weed (Astragalus), Four species of Lupin (Lupinus), Woolly Gromwell (Lithospermum ruderale), Large-flowered Phacelia (Phacelia linearis), Perennial Gilia (Gilia aggregata), Single-headed Everlasting (Antennaria dimorpha), Cutleaved Balsam-root (Balsamorrhiza hirsuta), Narrow-leaved Fleabane (Erigeron linearis), Broad-fruited Sun-flower (Helianthella Douglasii), Desert Pink (Stephanomeria tenuifolia).

\section{Alpine SPecies}

The alpine region has been defined by Rydberg as "the region between the perpetual snow and the timber line. The timber line is by no means a weli defined boundary line. It is in reality a broad zone in which the woody vegetation gradually thins out from the dense forest to the last krumholz" (gnarled and stunted trees).

As mentioned previously there are a considerable number of plants found in the Arctic Region which also occur in the Alpine regions of the mountains, as the habitat is somewhat similar in the two cases. There are, however, in the Western Region about thirty species of alpine plants which do not occur elsewhere in Canada. Among these are the following:-

\section{SHRUBS}

Alpine Willow (Salix nivalis) and two other species, Red Heather (Phyllodoce eripetriformis), White Heath (Cassiope Merterisiana).

\section{HERBS}

Alpine Hair-grass (Deschampsia alpicola), White Marsh-marigold (Caltha leptosepala), Long-podded Whitlow Grass (Draba lonchocarpa), Alpine Cinquefoil (Potentilla saximontana), Fleshy-leaved Saxifrage (Saxifraga Van Bruntioe) and six other species, Mountain Pink (Douglasia nivalis), Whorled Greek Valerian (Polemonium confertum), Dark Blue Scorpion Weed (Phacelia Lyallii), Alpine Painted Cup (Castilleja orcidentalis), Alpine Golden Rod (Solidago ciliosa). 


\section{INDEX TO GENERA MENTIONED}

A

Abies...........25, 45, 55, 56

Abronia

Acalypha...

Acer....

Achlys

Acnida.

Actaea...

Actinea. .

(l)

Adlumia

Adoxa

Agropyron...

Agrostis...

Aletris.

Alisma

Allionia

Allotropa

Alnus.

Amarantus...

Ambrosia

Amelanchier

Ammophila...

A morpha...

Amphicarpaea

Amsinck $a$....

Andromeda

Anemone...

Angelıca...

Antennaria...

Anychia......

Apargidiun

Aralia...

Arbut.................30, 49

Arbutus...24, 27, 34, 35, 55, 56

Arceuthobium.........11, 12, 35

Arctostaphylos............... 35, 45

Arethusa..

Arisaema.................. 4

Arnica.

Artemisia........30, 37, 52, 57

Asarum................30, 49, 56

Asclepias............... 51, 53

Asimina.................... 54

Aster.........20, 21, 37, 48, 49

Astragalus..........29, 37, 57

Athysanus...

\section{B}

Baeria

Balsamorhiza

Baptisia.

Bartonia.

Bartsia

Benzoin.

Betula.

B.dens.

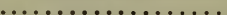

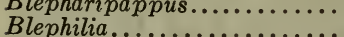

Blitum.....................

Boehmeria.................. 48

Bolelia.

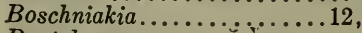

Bouteloua..

Brachyelytrum.

Brasenia..

Brickellia

Brodiaea.

Buchloë.

Buchnera. 48
C

$\mathrm{D}$

Cakile................20, 22

Calamagrostis.

Calceolaria................... 50

Calla..................... 18

Callıtriche...........13, 16, 17

Calochortus................. 55

Calopogon................ 48

Caltha...........17, 18, 56, 57

Calystegra............... 22

Campanula............... 44

Carex..................... 22, 37

Carpinus.................. 48

Carya.................. 47, 50

Cassiope................... 57

Castanea.......................... 50

48 Castilleja......................... 57

8 Caucalis....................... 55

3 Caulophyllum............35, 48

Ceanothus....................48, 56

5 Celastrus............... 35, 48

Celtis.................... 48

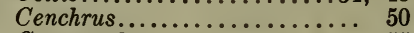

Centunculus................ 55

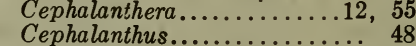

Cerastrum................... 43

Ceratophyllum.......... $14,15,16$

55 Cercis................... 50

95 Chaenactis.................... 55

2 Chamaecyparis..........26, 55, 56

Chamaelirium............... 50

Chelone.........................

Chenopodium....................... 22

Chrysanthemum........... 44

Cicuta......................... 19

Circaea..................33, 49

Cirsium................... 29

Cladium.................... 48

Cladothamnus............... 55

Clarkia..................... 55

Clematis............ $8,32,48$

Clintonia....................., 49

Cochlearia..................... 44

Coelopleurum............... 23

Collinsonia..................... 48

Collomia..................... 55

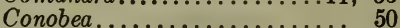

Conopholis....................... 12

Coptis................... 56

23, 55 Corallorrhiza.........11 $12 \quad 46$

Corema.................... 45,48

Cornus..........35 $4640.51,56$

Crataegus...........29, 35, 37

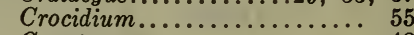

Cryptotaenı..................... 48

Cuscuta...................11, 12

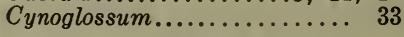
46

Dal.barda..........................

D

Dentar. $a \ldots \ldots \ldots \ldots \ldots \ldots \ldots \ldots \ldots \ldots \ldots \ldots \ldots \ldots \ldots, 49$

Deschampsia................

Desmodium.....................

Deyeuxia.

Dianthera...

Diapensia
Dioscorea.........6, 8, 32, 50

Dirca................... 47

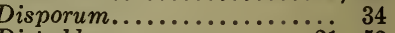

Distrchls.................. 52

Dodecatheon.............. 44

Douglasia..................... 57

Draba................. 43,57

Drosera................. 10

Dryas.................... 44

E

Echinocystis............. 8

Echinodorus..................

Echinopanax............. 55, 56

Elaeagnus................... 53

Elatine..................... 19

Eleocharis.................. 18

Elodea................ $14,16,48$

Elymus............20, 22, 37, 44

Empetrum................ 43

Epilobium...........32, 37, 46

Epiphegus..............12, 48

Erigenia............... 50

Erigeron................... 57

Eriocaulon..................... 47

Errogonum............. 57

Eriophorum.......... $32,44,46$

Eriophyllum.............. 55

Eryngium................ 55

Erythronium............. 59 i, 56

Euonymus.................. 50

Euphorbia.......... $20,22,31,51$

Eurotia...................52, 53

Eutrema................ 44

F

Fagus..............26, 48

Festuca.................... 43

Fimbristylis............. 50

Floerkea.................... 48

Fragaria.................. 34

Franseria.................... 22

Frasera................... 50

Fraxinus.....26, 32, 48, 50, 53

Fritıllaria.............. 55

G

Galıum............ 33,46

Gaultheria.................. 34,56

Gaura..................... 53

Gaylussacia..................... 48

Gayophytum.............. 55

Gentrana.............. $43,48,53$

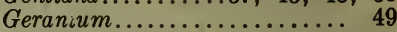

Gerardia..............20, 21

Geum...................... 33,49

Gilia...................... 57

Gillenia....................... 50

Glaux....................... 52

Gleditsia.................29, 50

Glehnia....................... 55

Glyceria............................. 37

Glycine................... 48

7 Glycyrrhiza................ 33

Grindelia.................... 30

43 Gutierrezia..................... 53

Gymnocladus............... 50 
$\mathrm{H}$

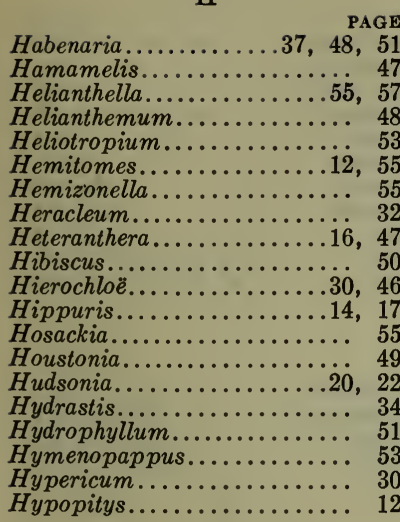

\section{I}

Ilex... 35,47

I pomoea.............. Isanthus.................. 48

Isopyrum

J

Jaumea.

Jeffersonia............... 50

Juglans.............26, 47, 50

Juncus......... $17,21,22,32,37$

Juniperus...........29, 34, 45

K

Kalmia

\section{L}

Lagotis...

Laportea....................

Larix............

Lathyrus................ 8,21

Layia...................... 55

Lechea...................... 48

Ledum....................... 44

Lemna............13, 14, 15,46

Leptarrhena............... 55

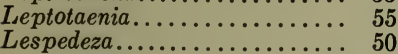

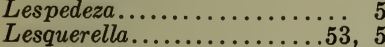

Lewisia.....................55, 57

Liatris.......................

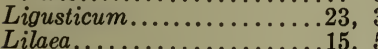

Lilaeopsis..................... 2

Limnanthes................ 55

Limnobium............... 34,50

Limonium................. 20

Limosella................... 18

Linnaea....................... 46

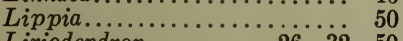

Liriodendron..........26, 32, 50

Lithospermum................ 57

Littorella.........13, 14, 16, 48
Lobelia...............13, 16

Loiseleuria.................43, 44

Lomatium................... 32

Lonicera........8, $34,35,45,48$

Lophiola................... 48

Lophotocarpus.............. 19,48

Ludwigia..............18, 19

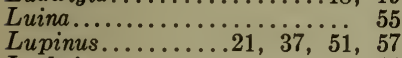

Lychnis...
L

Lygodesmia

Lysichiton.

PAGE

52

ysimachia................ 49

M

Mahonıa.

Magnolza.

Mammillaria................

Medeola..................34, 48

Megalodonta............... 17

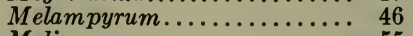

Melica.................. 55

Menispermum........... 34,47

Mentzelia................... 58

Menyanthes..........19, 28, 56

Menziesia.................. 55

Mertensia....................20, 22

Micromeria............... 55

Microseris................ 55

Microsterns.................... 55

Mikanıa...................., 50

Milium....

88

Mimulus................... 48

Minuartia................20, 22, 37

Mitchella.................... 48

Mitella.

Monarda......................

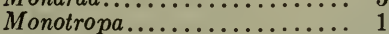

Morus................... 34, 50

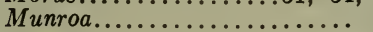

Musineon..........................

Myrica.

Myriophyllum............13, 14,17

$\mathrm{N}$

Najas...............13, 15, 16

Nasturtium................. 17

Nelumbo................. 18, 50

Nemophila.................. 55

Nesaea...................... 50

Nicotiana...................... 55

Nymphoides................ 48

Nymphozanthus.............. 56

Nyssa...........27, 35, 50

\section{$\mathrm{O}$}

Oenanthe

Oenothera.................55, 56

Onosmodium..................... 53

Opuntia......................29, 51

Orobanche.

Osmaronia........................ 56

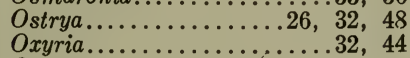

Oxytropis................... 44

$\mathbf{P}$

Pachystima............... 55

Panax.........................., 48

Panicum......................... 37

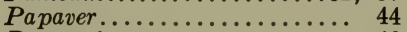

Parnassia.................. 46

Parrya...................... 44

Pedicularis................. 37,4

Peltandra................. 34, 50

Penthorum.................. 48

Peramium...................46, 49

Petalostemon.

Phacelia.

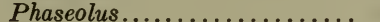

$\mathbf{P}$

Philadelphus............. PAGE

Phlox...................... 49

Phragmites.................. 32

Phryma..................... 47

Phyllodoce................ 51

Phyllospadix.............15, 55

Physalis........................ 34

Physocarpus...........48, 57

Phytolacca..............35, 50

Picea............25, 45, 55, 56

Pilea.................... 48

Pinguicula.................. 10

Pinus..25, 45, 48, 53, 55, 56, 57

Plantago.................... 21

Platanus....................... 50

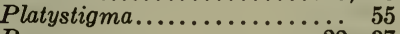

Poa................22, 37

Podophyllum.............34, 35, 48

Podostemum................ 46

Pogonia................... 48

Polemonium.................. 57

Polygonatum.........34, 48, 49

Polygonum.....8, 17, 28, 37, 43

Polymnia................ 50

Pontederia.............19, 47

Populus.....26, 30, 45, 53, 55

Potamogeton.13, 14, 15, 16, 17, 37, 46

Potentilla...19, 37, 44, 45, 53, 57

Prenanthes................ 49

Primula..................... 44

Proserpinaca...........17, 48

Prunus......27, 29, 34, 48, 53

Pseudotsuga..............25, 55

Psilocarphus............... 55

Psoralea...................... 53

Ptelea....................... 32

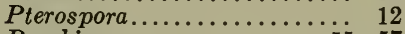

Purshia.................55, 57

Pycnanthemum................. 48

Pyrola.............44, 46, 49

Pyrus.............. 48, 51, 56

Q

Quercus.......26, 48, 50, 53, 56

$\mathrm{R}$

Ranunculus..16, 17, 22, 33, 37, $44,49,52,56,57$

Rhabdocrinum ............. 55 Rhamnus.................... 56 Rhexia..................... 50

Rhinanthus................ 32

Rhododendron.............4, 48

Rhus...7, 28, 30, 31, 34, 48, 51, 53

Rhynchospora........... 18 Ribes.28, $29,34,35,37,45,48,53,56$ Romanzoffia.............. 55 Rosa................ $29,34,37$ Rubus....... $8,29,34,37,48,56$ Rumex........18, 21, 32, 44, 53 Ruppia................15, 16

Sagittaria..............18, 19 Salicornia................20, 21 Salıx...................... 37 $43,44,45,56,57$ Sambucus........................... 56 Sanguinaria.................... 48

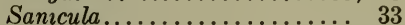
Sarracenia..................... 10 Sassafras...................... 50

Saururus..............18, 50

Saxifraga................. 44, 57

Schedonnardus................ 53

Scirpus...........17, 18, 21, 37 
60

S

Scleria

$\ldots \ldots \ldots . . .50$

Sericocarpus.......23, 37, 44, 48

Shepherdia.......29, 34, 45, 52

Sicyos................ 8, 48

Sidalcea...

Silene...............43, 44

Silphrum..................... 50

Sium.................... 19

Smelowskia................... 55

Smilacina................ 34

Smilax......6, 7, 8, 29, 34, 51

Solanum................. 35

Solidago........21, 37, 49, 57

Sparganium..............16, 18

Spartina.

Spergularia..............20, 21

Sphaeralcea.................. 55

Spiraea..................48, 53

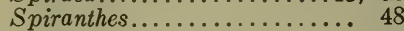

Stachys.................. 56

Staphylea............... 47

Statice................23, 32

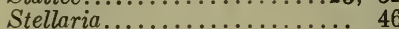

Stenanthium................ 55

Stephanomeria...........55, 57

Streptopus..............34, 46

Strophostyles.............. 8

Suaeda.................... 21

Subularna........13, 14. 15, 16

Symphoricarpos........34, 35, 53

Symplocarpus.
$\mathrm{T}$

Talinum

Tanacetum

Taxus...

Tecoma

\section{Tellima.......}

Tephrosia.......

Tetradym.

Thelesperma.............. 53

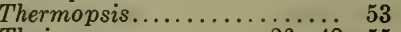

Thuja............... 48,55

Thysanocarpus.............. 55

Tiarella..................49, 56

Tigridia................. 55

Tilia.............27, 32, 47

Tolmiea.................. 55

Trautvetteria............ 55

Triglochin..................... 46

Trillıum...........34, 49, 56

Triosteum..............34, 35, 48

Triplasis..................... 50

Trollius................... 55

Tsuga............25, 48, 55

Typha............... 32

\section{U}

Ulmus......26, 30, 32, 48, 53 Zannichellia.

28 Zanthoxylum......................... 16

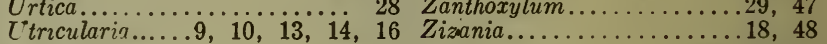

Uvularia................ 48 Zostera...................15, 16 



OTTAWA
F. A. ACLAND

PRINTER TO THE KING'S MOST EXCELLENT MAJESTY 1927 